\title{
Capacity to Elicit Cytotoxic CD8 T Cell Activity Against Mycobacterium avium subsp. paratuberculosis Is Retained in a Vaccine Candidate 35 kDa Peptide Modified for Expression in Mammalian Cells
}

OPEN ACCESS

Edited by:

Fabrizio Ceciliani,

University of Milan, Italy

Reviewed by:

Karren M. Plain,

University of Sydney, Australia Tomohiro Okagawa,

Hokkaido University, Japan

*Correspondence:

William C. Davis

davisw@wsu.edu

Gaetano Donofrio

gaetano.donofrio@unipr.it

†These authors have contributed equally to this work

Specialty section:

This article was submitted to

Comparative Immunology,

a section of the journal

Frontiers in Immunology

Received: 02 August 2019 Accepted: 21 November 2019 Published: 11 December 2019

Citation:

Franceschi V, Mahmoud AH, Abdellrazeq GS, Tebaldi G, Macchi F

Russo L, Fry LM, Elnaggar MM, Bannantine JP, Park K-T, Hulubei V, Cavirani S, Davis WC and Donofrio G (2019) Capacity to Elicit Cytotoxic CD8 T Cell Activity Against

Mycobacterium avium subsp. paratuberculosis is Retained in a Vaccine Candidate 35 kDa Peptide Modified for Expression in Mammalian

Cells. Front. Immunol. 10:2859. doi: 10.3389/fimmu.2019.02859
Valentina Franceschi ${ }^{1 \dagger}$, Asmaa H. Mahmoud ${ }^{2,3+}$, Gaber S. Abdellrazeq ${ }^{2,4}$, Giulia Tebaldi ${ }^{1}$, Francesca Macchi ${ }^{1}$, Luca Russo ${ }^{1}$, Lindsay M. Fry ${ }^{2,5}$, Mahmoud M. Elnaggar ${ }^{2,3}$, John P. Bannantine ${ }^{6}$, Kun-Taek Park ${ }^{7}$, Victoria Hulubei ${ }^{2}$, Sandro Cavirani ${ }^{1}$, William C. Davis ${ }^{2 *}$ and Gaetano Donofrio ${ }^{1 *}$

${ }^{1}$ Department of Medical-Veterinary Science, University of Parma, Parma, Italy, ${ }^{2}$ Department of Veterinary Microbiology and Pathology, Washington State University, Pullman, WA, United States, ${ }^{3}$ Veterinary Quarantine of Alexandria, General Organization for Veterinary Services, Ministry of Agriculture, Alexandria, Egypt, ${ }^{4}$ Department of Microbiology, Faculty of Veterinary Medicine, Alexandria University, Alexandria, Egypt, ${ }^{5}$ Animal Disease Research Unit, Agricultural Research Service (ARS), USDA, Pullman, WA, United States, ${ }^{6}$ National Animal Disease Center, Agricultural Research Service (ARS), USDA, Ames, IA, United States, ${ }^{7}$ Department of Biotechnology, Inje University, Gimhae, South Korea

Studies focused on development of an attenuated vaccine against Mycobacterium avium subsp. paratuberculosis (Map), the causative agent of paratuberculosis (Ptb) in cattle and other species, revealed that deletion of relA, a global gene regulator, abrogates the ability of Map to establish a persistent infection. In the absence of relA, cattle develop CD8 cytotoxic $T$ cells (CTL) with the ability to kill intracellular bacteria. Analysis of the recall response to a relA mutant, Map/ $\Delta r e l A$, with cells from a vaccinated steer demonstrated that a $35-\mathrm{kDa}$ membrane peptide (MMP) is one of the targets of the response. This observation suggested that it might be possible to develop a peptide-based vaccine. As reported here, the gene encoding the hypothetical MMP ORF, MAP2121c, was modified for expression in mammalian cells as a first step in developing an expression cassette for incorporation into a mammalian expression vector. The modified sequence of MMP, tPA-MMP, was mutated to generate two additional sequences for the study, one with substitutions to replace five potential residues that could be glycosylated, tPA-MMP-5mut, and one with substitutions to replace the first two potential residues that could be glycosylated, tPA-MMP-2mut. The sequences were placed in an expression cassette to produce peptides for analysis. An ex vivo platform was used with flow cytometry and a bacterium viability assay to determine if modifications in the gene encoding MMP for expression in mammalian cells altered its capacity to elicit development of CD8 $C T L$, essential for its use in a peptide-based vaccine. Monocyte-depleted PBMC (mdPBMC) were stimulated with antigen-presenting cells (APC) pulsed with different MMP constructs. CD4 and CD8 T cells proliferated in response to stimulation with MMP (control) expressed in Escherichia coli (eMMP), tPA-MMP, and tPA-MMP-2mut. CD8T 
cells retained the capacity to kill intracellular bacteria. The tPA-MMP-5mut failed to elicit a proliferative response and was not included in further studies. The data show that the expression cassettes containing MMP and MMP-2mut can be used to screen and select a mammalian expression vector for the development of an efficacious peptide-based vaccine against Ptb.

Keywords: Ptb, MMP, mammalian expression vector, immune response, vaccine

\section{INTRODUCTION}

Mycobacterium avium subsp. paratuberculosis (Map) is a mycobacterial pathogen with a broad host range that includes livestock, humans, and wildlife (1-5). It is the causative agent of paratuberculosis (Ptb) in livestock. Ptb (also referred to as Johne's disease) has become a major disease problem in dairy ruminants, especially in cattle. Similar to other pathogenic mycobacteria, initial infection leads to development of a persistent infection under immune control. For yet unknown reasons, this protective immunity is dysregulated two or more years post-infection, allowing for development of clinical disease. The inability to detect infected animals during the early (latent) stages of infection has led to the inadvertent spread of Ptb via introduction of latently infected animals into clean herds worldwide. Attempts to clear Map from livestock herds using management strategies and improved early diagnostic methods has not been successful (6-10). Thus, development of a Map livestock vaccine is urgently needed.

Past efforts with killed vaccines revealed that vaccination reduces the incidence of clinical disease, but does not prevent establishment of infection and fecal shedding $(11,12)$. Similar results have been reported with peptide-based vaccines (13, 14). Subsequently, attenuated Map strains were developed as potential live vaccines, and efforts to discover potential peptide vaccine targets continue $(13,15,16)$. A major limitation of previous and ongoing endeavors has been the lack of methods to fully evaluate the immune response to candidate live and peptide-based vaccines. As a consequence, there has been a lingering question as to whether there is an age-related difference in susceptibility or immune-responsiveness to Map infection that confers long-lasting immunity in adult animals (6). We developed the reagents and methods needed to study the ex vivo

\footnotetext{
Abbreviations: APC, antigen-presenting cells; pA, bovine growth hormone polyadenylation signal; CBS, calf bovine serum; CTL, cytotoxic $\mathrm{T}$ cells; cRPMI, complete culture medium; cDC, conventional dendritic cells; DMSO, dimethyl sulfoxide; EMEM, Eagle's minimal essential medium; EDTA, ethylenediaminetetraacetic acid; FBS, fetal bovine serum; GFP, green fluorescence protein; CMV, human cytomegalovirus; $\mathrm{EF} 1 \alpha$, human elongation factor 1 alpha promoter; HEK, human embryo kidney; HKB-11, human kidney/B cell hybrid; tPA, human tissue plasminogen activator signal peptide; Map, Mycobacterium avium subsp. paratuberculosis; eMMP, MMP expressed in E. coli; MoDC, monocyte-derived dendritic cells; mdPBMC, monocytes depleted PBMC; MoMФ, monocyte derived macrophages; GlcNAc, N-acetyl-D-glucosamine; NP, nanoparticles; Ptb, paratuberculosis; PBMC, peripheral blood mononuclear cells; PBS, phosphate buffered saline; PEI, polyethylenimine; PMA-QPCR, propidium monoazide quantitative PCR; qRT-PCR, quantitative real-time PCR; MMP, 35 $\mathrm{kDa}$ membrane peptide.
}

immune response to Map to answer this question, and to analyze the immune response to candidate vaccines.

Initial studies comparing the immune response to Map in experimentally and naturally infected cattle revealed a possible age-related difference in the development of the CD8 T cell response to mycobacterial antigens $(17,18)$. The proliferative response of $\mathrm{CD} 4 \mathrm{~T}$ cells to mycobacterial antigens was early and vigorous in experimentally infected calves, and the CD8 T cell response increased over time (18). The CD4 and CD8 T cell proliferative responses to mycobacterial antigens were strong in naturally infected cattle. Although differences in immune responses were detected, no age-related difference in susceptibility to infection was found. Adaptation of methods to use site-directed mutagenesis with Map provided an opportunity to develop and compare the immune response to mutants with deletions in genes associated with virulence (19). We were particularly interested in relA, a global gene regulator. Studies with a relA deletion mutant in Mycobacterium tuberculosis (Mtb) in a mouse model revealed that the mutant was unable to establish a persistent infection (20).

A relA deletion mutant was developed in Map ( $\triangle$ Map/relA), and a similar decrease in bacterial survival was noted (21). Analysis of the ex vivo immune response revealed the loss of ability to establish a persistent infection was attributable to development of CD8 cytotoxic T cells (CTL) with the ability to kill intracellular bacteria, a function essential for development of an attenuated mutant vaccine for Map (22). Further analysis of the recall response to $\triangle$ Map/relA using PBMC from a steer vaccinated with the $\triangle M a p /$ relA mutant revealed that the target of the response was a $35-\mathrm{kDa}$ membrane-associated molecule encoded by MAP2121c, MMP $(22,23)$. Comparison of the recall response demonstrated a comparable CTL response could be elicited with live $\triangle M a p / r e l A$ or MMP, suggesting that it might be possible to develop an MMP peptide-based vaccine. Ex vivo studies demonstrated that the same CD8 CTL activity could be elicited with antigen-presenting cells (APC) pulsed with MMP alone or incorporated into a nanoparticle-based vector (24). The most recent studies revealed two important findings. The first is that the nanoparticle (NP)-based approach to peptidebased vaccination is not the best for production of a vaccine for field use, and that other methods should be explored. The second finding relevant to development of vaccines in general is that development of CD8 CTL against MMP only occurred if $\mathrm{CD} 4$ and $\mathrm{CD} 8 \mathrm{~T}$ cells recognized their respective antigenic epitopes, presented by APC, at the same time (submitted for review). The proliferative and CD8 CTL response to antigens presented by APC pulsed with MMP was blocked in the presence 
of antibody to either MHC class I or class II molecules. This finding revealed that any form of MMP developed for use in a vaccine must be designed in a configuration that retains the features of the native molecule associated with antigen processing for cross-presentation of peptides in the context of MHC class I and class II molecules.

The present study was conducted to determine if the native gene sequence encoding MMP could be modified for expression in mammalian cells and retain its full immunogenic properties, a prerequisite for its potential use in a vector designed for expression in mammalian cells.

\section{MATERIALS AND METHODS}

\section{Mammalian Cell Lines}

Human Embryo Kidney (HEK) 293T (ATCC: CRL-11268) and Human Kidney/B Cell Hybrid (HKB-11) (ATCC: CRL12568) cells were maintained as suggested by the manufacturer's instructions. All cell lines were cultured in Eagle's Minimal Essential Medium (EMEM, Gibco) containing 10\% fetal bovine serum (FBS), $2 \mathrm{mM}$ of L-glutamine (Gibco), $100 \mathrm{IU} / \mathrm{ml}$ of penicillin (Gibco), $100 \mu \mathrm{g} / \mathrm{ml}$ of streptomycin (SIGMA), and $0.25 \mu \mathrm{g} / \mathrm{ml}$ of amphotericin B (Gibco), and were incubated at $37^{\circ} \mathrm{C} / 5 \% \mathrm{CO}_{2}$ in a humidified incubator.

\section{Sequence Analysis and Cloning of MMP}

The human codon-usage adapted MMP synthetic ORF was modified from the published sequence for the hypothetical protein MAP_2121c, Map K-10 (NCBI GenBank: AAS04438.1). In this synthetic construct, a Kozak's sequence, the human tissue plasminogen activator signal peptide (tPA), and an AU1 peptide tag were added to the human-adapted ORF sequence at the $5^{\prime}$ terminus and at the $3^{\prime}$ terminus, respectively, generating tPAMMP. In addition, two synthetic mutants, tPA-MMP-5mut and tPA-MMP-2mut, were generated. In this step, all five predicted $\mathrm{N}$-glycosylation sites (tPA-MMP-5mut) or only the first two predicted N-glycosylation sites (tPA-MMP-2mut) were mutated.

Using PCR amplification, restriction sites were added to the $3^{\prime}$ and $5^{\prime}$ termini of tPA-MMP, tPA-MMP-5mut, and tPA-MMP-2mut to facilitate subsequent cloning. Briefly, the primer pair NheI-p35-sense (5'-CCCCGCTAGCCCACCATG GACGCTATGAAGAGGGGCCTGTGCTGC-3') and SmaI-p35antisense (5'-CCCCCCCGGGTTAGATGTACCGGTAGGTGT CCTTGTACTC- $3^{\prime}$ ) was used to insert a NheI restriction site at the $5^{\prime}$ end and a SmaI restriction site at the $3^{\prime}$ end of the ORF. The PCR amplification reaction was performed in a final volume of $50 \mu \mathrm{l}$, containing $10 \mathrm{mM}$ Tris-hydrochloride $\mathrm{pH}$ $8.3,10 \%$ dimethyl sulfoxide (DMSO), $0.2 \mathrm{mM}$ deoxy nucleotide triphosphates, $2.5 \mathrm{mM} \mathrm{MgSO}_{4}, 50 \mathrm{mM} \mathrm{KCl}$, and $0.25 \mu \mathrm{M}$ of each primer. tPA-MMP, tPA-MMP-5mut, and tPA-MMP-2mut DNA were first linearized with HindIII to facilitate polymerase action and then amplified over 35 cycles consisting of 1 min of denaturation at $94^{\circ} \mathrm{C}, 1 \mathrm{~min}$ of primer annealing at $60^{\circ} \mathrm{C}$, and 1 min of chain elongation with $1 \mathrm{U}$ of Pfu DNA polymerase (Thermo Scientific) at $72^{\circ} \mathrm{C}$. The amplicons were subsequently checked in $1 \%$ agarose gel and visualized using ethidium bromide staining in $1 \times$ TAE buffer (40 mM Tris-acetate, $1 \mathrm{mM}$ EDTA).
Later, the NheI/SmaI cut amplicons were cloned into the shuttle vector pINT2EGFP (25) and cut with the same enzymes, generating pCMV-tPA-MMP, pCMV-tPA-MMP-5mut, and pCMV-tPA-MMP-2mut, thereby placing the tPA-MMP ORFs under the transcriptional control of the immediate early gene promoter of human cytomegalovirus (CMV), followed by the bovine growth hormone polyadenylation signal (pA). Alternatively, the NheI/SmaI cut amplicons were subcloned into the vector pEF1 $\alpha$-p67 (26) to put the tPA-MMP ORFs under the transcriptional control of the Human Elongation Factor 1 Alpha $(\mathrm{EF} 1 \alpha)$ promoter followed by the bovine growth hormone $\mathrm{pA}$, thus generating pEF1 $\alpha$-tPA-MMP, pEF1 $\alpha$-tPA-MMP-5mut, and $\mathrm{pEF} 1 \alpha$-tPA-MMP-2mut.

The pEF1 $\alpha$-tPA-MMP-CMV-EGFP:T2A:Puro lentiviral vector was obtained by subcloning the NheI/SmaI cut, tPA-MMP amplicon into the third-generation, replication-incompetent, lentiviral vector pLV-EGFP:T2A:Puro (Cyagen), linearized using NheI/EcoRV digestion, to place the modified tPA-MMP sequence under the transcriptional control of the EF1 $\alpha$ promoter.

\section{PNGase F Digestion}

PNGase F (New England BioLabs) was used as suggested by the manufacturer. Briefly, serum-free medium supernatants from pEF1 $\alpha$-tPA-MMP, pEF1 $\alpha$-tPA-MMP-5mut, and pEF1 $\alpha$ tPA-MMP-2mut-transfected HEK cells, collected after $72 \mathrm{~h}$ of secretion, were digested with PNGase F, which cleaves between the innermost N-Acetyl-D-Glucosamine (GlcNAc) and asparagine residues from $\mathrm{N}$-linked glycoproteins. Twenty micrograms of glycoproteins was denatured at $100^{\circ} \mathrm{C}$ for $10 \mathrm{~min}$ in the presence of $10 \times$ Glycoprotein Denaturing Buffer; after chilling on ice and a brief centrifuge of $10 \mathrm{~s}$, GlycoBuffer 2 $(10 \times)$, NP-40 $10 \%$, water, and $1 \mu$ l of PNGase F $(500,000$ $\mathrm{U} / \mathrm{ml}$ ) were added. The reaction was incubated for $1 \mathrm{~h}$ at $37^{\circ} \mathrm{C}$. After PNGase digestion, tPA-MMP was detected using Western immunoblotting as described below.

\section{Transient Transfection and Secretion of tPA-MMP From Hek 293T Cells}

To evaluate the expression and secretion of tPA-MMP, HEK $293 \mathrm{~T}$ cells were transiently transfected with pCMV-tPA-MMP, pCMV-tPA-MMP-5mut, pCMV-tPA-MMP-2mut, pEF1 $\alpha$-tPAMMP, pEF1 $\alpha$-tPA-MMP-5mut, pEF1 $\alpha$-tPA-MMP-2mut, pEF1 $\alpha$ tPA-MMP-CMV-EGFP:T2A:Puro, pEF1 $\alpha$-iresGFP (pWPI, from Addgene), or pEGFP-C1 (Clontech), using polyethylenimine (PEI) transfection reagent (Polysciences, Inc.). Briefly, cells were seeded at $3 \times 10^{5}$ cells/well in six-well plates and incubated overnight at $37^{\circ} \mathrm{C} / 5 \% \mathrm{CO}_{2}$ in a humidified incubator. Cells were then incubated for $6 \mathrm{~h}$ with a transfection mix containing $3 \mu \mathrm{g}$ of plasmid DNA and PEI (ratio 1:2.5 DNA-PEI) in Dulbecco's modified essential medium (DMEM) high glucose (Euroclone) without serum. After incubation, the transfection mix was replaced by fresh medium EMEM, with 10\% FBS, 100 $\mathrm{IU} / \mathrm{ml}$ of penicillin, $100 \mu \mathrm{g} / \mathrm{ml}$ of streptomycin, and $0.25 \mu \mathrm{g} / \mathrm{ml}$ of amphotericin B, and incubated for $24 \mathrm{~h}$ at $37^{\circ} \mathrm{C} / 5 \% \mathrm{CO}_{2}$ in a humidified incubator. To test supernatant protein expression, the transfection solution was replaced with fresh DMEM/F12 (ratio 1:1) medium without FBS and incubated for $48 \mathrm{~h}$ at $37^{\circ} \mathrm{C} / 5 \% \mathrm{CO}_{2}$ 
in a humidified incubator. Cell supernatant was then collected and analyzed by immunoblot.

\section{Lentivirus Reconstitution and Transduction}

HEK 293T cells were transfected in a T175 $\mathrm{cm}^{2}$ flask with $25 \mu \mathrm{g}$ of pEF1 $\alpha$-tPA_MMP-CMV-EGFP:T2A:Puro or pEF1 $\alpha$ iresGFP transfer vectors, $13 \mu \mathrm{g}$ of $\mathrm{p} 8.74$ packaging vector, $10 \mu \mathrm{g}$ of pMD2 pseudotyping vector, and $10 \mu \mathrm{g}$ of pREV using PEI transfection reagent (Polysciences, Inc.). Briefly, $58 \mu \mathrm{g}$ of DNA was mixed with $145 \mu \mathrm{g}$ of PEI $(1 \mathrm{mg} / \mathrm{ml})$ (ratio 1:2.5 DNA-PEI) in $3 \mathrm{ml}$ of Dulbecco's modified essential medium (DMEM) high glucose (Euroclone) without serum. After $15 \mathrm{~min}$ of incubation at room temperature, $4 \times$ volumes of medium without serum were added and the transfection solution was transferred to the cell monolayer and left for $6 \mathrm{~h}$ at $37^{\circ} \mathrm{C} / 5 \% \mathrm{CO}_{2}$, in a humidified incubator. The transfection mixture was then replaced with $25 \mathrm{ml}$ of fresh medium EMEM supplemented with 10\% FBS, 50 $\mathrm{IU} / \mathrm{ml}$ of penicillin, $50 \mu \mathrm{g} / \mathrm{ml}$ of streptomycin, and $2.5 \mu \mathrm{g} / \mathrm{ml}$ of amphotericin $\mathrm{B}$, and cells incubated for $48 \mathrm{~h}$ at $37^{\circ} \mathrm{C} / 5 \% \mathrm{CO}_{2}$. The flask was then stored at $-80^{\circ} \mathrm{C}$. Lentivirus was later obtained by subjecting cells to three freeze-thaw cycles and then clarifying the supernatant via centrifugation at $3500 \mathrm{rpm}$ for $5 \mathrm{~min}$ at $4{ }^{\circ} \mathrm{C}$ and filtering through a $0.45-\mu \mathrm{m}$ filter (Millipore). The clarified, lentivirus-containing supernatant was stored at $-80^{\circ} \mathrm{C}$. To obtain stably transduced cell lines, $1 \times 10^{5} \mathrm{HKB}-11$ cells were infected with $2 \times 10^{5}$ T.U. (transducing units) of reconstituted tPA-MMP lentivirus. Cells were incubated overnight at $37^{\circ} \mathrm{C} / 5 \%$ $\mathrm{CO}_{2}$. The culture medium was then replaced with fresh medium supplemented with $10 \%$ of FBS. Transduced cells were observed daily via fluorescence microscopy for green fluorescence protein (GFP) expression to monitor the rate of transduction and were selected with $1 \mu \mathrm{g} / \mathrm{ml}$ of Puromycin to achieve a $100 \%$ transduction rate.

\section{Immunoblot}

Protein cell extracts were obtained from pCMV-tPA-MMP, pCMV-tPA-MMP-5mut, pCMV-tPA-MMP-2mut, pEF1 $\alpha$-tPAMMP, pEF1 $\alpha$-tPA-MMP-5mut, pEF1 $\alpha$-tPA-MMP-2mut, and pEGFP-C1 transfected HEK 293T, or from tPA-MMP lentivirus stably transduced HKB-11 cells and non-transduced control HKB-11 cells by adding $100 \mu \mathrm{l}$ of cell extraction buffer (50 mM Tris-HCl, $150 \mathrm{mM} \mathrm{NaCl}$, and 1\% NP-40; pH 8). After BCA total protein quantification (Pierce ${ }^{\mathrm{TM}}$ BCA Protein Assay kit, Thermo Scientific), cell extracts containing various amount of total protein were electrophoresed through 10\% SDSPAGE. Proteins were then transferred to nylon membranes by electroblotting, and membranes were incubated with anti-AU1 rabbit polyclonal antibody (A190-125A, Bethyl Laboratories Inc.) diluted 1:10.000, washed, and then incubated with a goat antirabbit secondary antibody labeled with horseradish peroxidase (Sigma), diluted 1:15,000 and visualized by enhanced chemiluminescence (Clarity Max western ECL substrate, Biorad). Also, cell supernatants, obtained from HEK 293T cells transfected with pCMV-tPA-MMP, pCMV-tPA-MMP-5mut, pCMV-tPA-MMP2 mut, pEF1 $\alpha$-tPA-MMP, pEF1 $\alpha$-tPA-MMP-5mut, pEF1 $\alpha$-tPAMMP-2mut, and pEGFP-C1 and from all the transduced cell lines, were collected after $72 \mathrm{~h}$ in serum-free medium DMEMF12 secretion condition and analyzed through 10\% SDS-PAGE gel electrophoresis.

\section{Blood Source}

Blood required to conduct the study of the immune response to mammalian-expressed MMP peptides was obtained from three Map-free Holstein steers housed in an open feed lot and maintained by the WSU animal care staff. All protocols were approved by the Washington State University Institutional Animal Care and Use Committee (ASAFs 3360 and 04883).

\section{Cell Separation and Culture}

Peripheral blood mononuclear cells (PBMC) were prepared by density gradient centrifugation. One portion of the PBMC was used to generate monocyte-derived macrophages (MoM $\Phi)$ for use in a propidium monoazide quantitative PCR (PMAQPCR) viability assay (22). This portion of the PBMC was re-suspended in complete RPMI culture medium (cRPMI) [RPMI-1640 medium with GlutaMAX ${ }^{\mathrm{TM}}$ (Life Technologies, CA) supplemented with $10 \%$ calf bovine serum (CBS), $1 \mathrm{mM} \beta$ mercaptoethanol, 100 units/ml of penicillin $\mathrm{G}$, and $100 \mu \mathrm{g} / \mathrm{ml}$ of streptomycin sulfate] and cultured overnight in $150-\mathrm{mm}$ tissue culture plates. The following day, non-adherent cells were removed and adherent cells were cultured in fresh medium for 6 days. On day six, the adherent cells were brought into suspension by incubation on ice in the presence of ethylenediaminetetraacetic acid (EDTA) in phosphate buffered saline (PBS) [ $4 \mathrm{ml}$ EDTA ( $250 \mathrm{mM}$ stock in $\mathrm{H}_{2} \mathrm{O}$ ), $5 \mathrm{ml}$ CBS, and $91 \mathrm{ml} \mathrm{PBS}]$. Then, the $\mathrm{MoM} \Phi$ were distributed into six-well culture plates $\left(2 \times 10^{6}\right.$ cells/well $)$ and cultured for an additional 6 days in fresh cRPMI at $37^{\circ} \mathrm{C} / 5 \% \mathrm{CO}_{2}$.

The second PBMC portion was subjected to magnetic separation using microbeads coated with a cross-reactive antihuman CD14 mAb to isolate monocytes per the manufacturer's instructions (Miltenyi Biotec) (27). Isolated monocytes $\left(2 \times 10^{6}\right)$ were added to wells of six-well culture plates and cultured in $3 \mathrm{ml}$ of cRPMI in the presence of a DC growth cocktail containing bovine GM-CSF and IL-4 according to the manufacturer instructions (Kingfisher Biotech, MN). On the third day, $1.4 \mathrm{ml}$ of the medium was replaced with $1.8 \mathrm{ml}$ of fresh medium containing the cocktail. The cultures were incubated for an additional 3 days to obtain monocyte-derived dendritic cells (MoDC).

Flow-through containing monocyte-depleted PBMC (mdPBMC) were subjected to two rounds of antigenic stimulation using APC (cDC present in mdPBMC) $(22,28)$ pulsed with MMP expressed in E. coli (eMMP) (29) or tPA-MMP, tPA-MMP-5mut, or tPA-MMP-2mut. To conduct the first round of stimulation, mdPBMC were distributed in the six-well culture plate in duplicate $\left(2 \times 10^{6} / \mathrm{ml}\right.$ in $5 \mathrm{ml}$ of cRPMI). Peptides were added to the indicated wells in a concentration of $5 \mu \mathrm{g} / \mathrm{ml}$, and the cultures incubated for 6 days at $37^{\circ} \mathrm{C}, 5 \% \mathrm{CO}_{2}$ to allow antigen processing and presentation by conventional dendritic cells (cDC) present in the mAPBMC. To conduct the second round of stimulation after 6 days of culture, peptides were added to the cultures of MoDC at the same concentration and incubated for $3 \mathrm{~h}$ at $37^{\circ} \mathrm{C}, 5 \% \mathrm{CO}_{2}$. Then, peptide-pulsed MoDC 
TABLE 1 | mAbs used in the present study.

\begin{tabular}{llll}
\hline mAb clone & Isotype & Specificity/source & Fluorochrome \\
\hline CAM36A & $\operatorname{lgG1}$ & CD14 WSUMAC & Alexa Fluor ${ }^{\circledR} 647$ \\
209MD26A & $\operatorname{lgG} 2 \mathrm{a}$ & CD209 WSUMAC & PE CY5.5 \\
ILA11A & $\operatorname{lgG} 2 a$ & CD4 WSUMAC & PE CY5.5 \\
CACT138A & $\operatorname{lgG1}$ & CD4 WSUMAC & Alexa Fluor ${ }^{\circledR} 647$ \\
7C2B & $\operatorname{lgG} 2 a$ & CD8 WSUMAC & PE CY5.5 \\
CACT80C & $\operatorname{lgG1}$ & CD8 WSUMAC & Alexa Fluor ${ }^{\circledR} 647$ \\
ILA116A & $\operatorname{lgG3}$ & CD45R0 WSUMAC & Alexa Fluor ${ }^{\circledR} 488 ;$ PE CY7 \\
CACT116A & $\operatorname{lgG1}$ & CD25 WSUMAC & Alexa Fluor ${ }^{\circledR} 647$ \\
\hline
\end{tabular}

Data were collected on a modified FACS Calibur DXP8 Analyzer equipped with a FlowJo operating system (Cytek Biosciences Inc., Fremont, CA) and analyzed with FCS Express software (DeNovo Software, Glendale, CA) (30). For data acquisition, side scatter (SSC) and forward scatter (FSC) were used to identify small and large lymphocytes. FSCHeight vs. FSC-Width (FSC-H vs. FSC-W) was used to exclude doublets. Additional gates were used to select $C D 4$ and $C D 8 T$ cells for determination of their activation status and proliferation.

were washed three times with warm RPMI to remove cell-free antigens. The non-adherent primed PBMC were collected, washed with warm RPMI, and then added to their respective, autologous, antigen-pulsed MoDC $\left(2 \times 10^{6} / \mathrm{ml}\right.$ in $5 \mathrm{ml}$ of cRPMI). After an additional 6 days of culture, the cells were collected and used in FC and the Map PMA-QPCR viability assay as described below. One set of mdPBMC were maintained as negative controls with no antigen stimulation during the 2 weeks of cell culture.

\section{Flow Cytometry}

Cell activation and proliferation were assessed using FC as previously described (22). Briefly, cells were washed once in $\mathrm{PBS} / \mathrm{ACD}$, re-suspended in serum-free RPMI, and counted. Cells were distributed into 96-well polystyrene V-bottom microplates $\left(10^{6}\right.$ cells/well $)$ and labeled with combinations of mAbs obtained from the WSU Monoclonal Antibody Center (WSUMAC) (Table 1).

\section{PMA-QPCR Viability Assay}

To determine the cytotoxic activity of effector $\mathrm{T}$ cells generated after two rounds of stimulation with the different peptides, the live Map burden in infected MoM $\Phi$ co-cultured with the effector $\mathrm{T}$ cells was assessed using the PMA-QPCR viability assay. In this case, one aliquot of Map K10 stock (ATCC BAA-968/K10) was inoculated in Middlebrook 7H9 broth (Difco, BD Biosciences, USA) supplemented with 6.7\% para-JEM GS (Trek Diagnostic Systems, OH), $2 \mu \mathrm{g} / \mathrm{ml}$ mycobactin J (Allied Monitor, MO, USA), and $0.05 \%$ Tween 80 (Sigma-Aldrich Corp.) $(19,21)$. The cultures were expanded on a shaking stand at $37^{\circ} \mathrm{C}$ until they reached an $\mathrm{OD}_{600}$. Master stock for immediate use in each experiment was prepared in $1.5 \mathrm{ml}$ micro-centrifuge screw-cap tubes. Bacterial suspension was disaggregated by passages through a 26-gauge needle three times, and bacterial numbers were estimated based on the final $\mathrm{OD}_{600}$ values (19) and used for MoMФ infection.

MoM $\Phi$ were infected with Map K10 at a multiplicity of infection (MOI) of 10:1 $\left(2 \times 10^{7}\right.$ Map to $\sim 2 \times 10^{6} \mathrm{MoM} \Phi /$ well $)$ in antibiotic-free cRPMI for $3 \mathrm{~h}$ as previously described (22). Antigen stimulated and control unstimulated mdPBMC were collected and co-cultured with the infected MoM $\Phi$ for $24 \mathrm{~h}$ at $37^{\circ} \mathrm{C}, 5 \% \mathrm{CO}_{2}$. All non-adherent and adherent cells per well were collected and lysed for $15 \mathrm{~min}$ using $0.01 \%$ saponin in $\mathrm{H}_{2} \mathrm{O}$ at $37^{\circ} \mathrm{C}$. A set of controls (100\% live, $50 \%$ live/50\% killed, and $100 \%$ killed) was prepared from known mixtures of live and dead Map K10 to cover the dynamic range of Cycle threshold $\left(\mathrm{C}_{\mathrm{T}}\right)$ values for live vs. dead Map obtained from infected MoМ $\Phi$ before and after incubation with the effector cells. Each aliquot contained 2 $\times 10^{7}$ total Map. Aliquots were used to infect MoM $\Phi$ cultures as described followed by co-culture with $10^{7}$ fresh mdPBMC per well. Then, all cells in each well were immediately lysed with saponin as described above. All lysates were then treated with propidium monoazide (PMA) in a final dye concentration of $50 \mu \mathrm{M}$ as previously described (22) followed by light exposure for $5 \mathrm{~min}$ using a halogen lamp with a $650 \mathrm{~W}$ bulb. Cells were subsequently processed for DNA isolation according to the protocol for Gram-positive bacteria using DNeasy ${ }^{\circledR}$ Blood and Tissue kit (Qiagen, USA) as described by Park et al. (31).

The single-copy F57 gene specific for Map was used in the TaqMan Quantitative Real-Time PCR (F57 qRT-PCR) to determine the viability of intracellular Map as described by Kralik et al. (32) and Abdellrazeq et al. (22). Pure Map gDNA was used to generate a standard curve using eight dilutions starting with $4 \times 10^{7}$ copies. The reaction was performed according to Schönenbrücher et al. (33) using a StepOnePlus Real-Time PCR machine (Applied Biosystems, CA). The mean values of the $\mathrm{C}_{\mathrm{T}}$ were analyzed using StepOne Software v2.1 (Applied Biosystems, CA).

\section{Statistics}

Data were imported into SAS software (SAS for Windows version 9.3 and JMP version 12.0.1; SAS Institute Inc., Cary, NC) for statistical analysis and graphical presentation (means and standard deviations). Two-way ANOVA was used to conduct statistical analyses. Post-hoc multiple comparisons were conducted using Tukey HSD (overall $\alpha=0.05$ ). ${ }^{*} P<0.05$; ${ }^{* *} P<$ $0.01 ;{ }^{* * *} P<0.001$.

\section{RESULTS}

\section{Topological Prediction}

Initial data obtained with MMP demonstrated that it is a good candidate antigen for use in a peptide-based vaccine (22). MMP incorporated into an NP vector retained its CTL activity (24). However, methods for incorporating the peptide into the NP vector proved unreliable with some preparations having no activity. Therefore, we explored the potential of modifying the gene encoding MMP for expression in a mammalian expression vector for use in cattle and other species. It was unclear whether modifications in the amino acid sequence needed for expression in mammalian cells would alter the immunogenicity of MMP. Initial studies suggested that MMP is membrane associated (29). Further studies revealed that the peptide is associated with a cysteine desulferase (MAP2120c) in the membrane (23). In the present study, in silico analysis 
using the Phobius (http://phobius.sbc.su.se/) prediction server for presence of transmembrane domains and signal peptides did not detect a canonical signal peptide or hydrophobic region (Supplementary Figure 1). Indeed, an MMP-like sequence in mammalian cells appeared to be intracellularly localized and very soluble.

\section{Codon Usage Adaptation and Synthetic Gene Design}

Since MMP is a bacterial protein, codon usage had to be modified before attempting to develop an expression cassette for use in mammalian cells. This was accomplished with use of the Jcat codon adaptation tool to change the MMP ORF nucleotide codon composition to a composition based on human genome codon usage (http://www.jcat.de/) (Supplementary Figure 2). A Kozak's sequence and a human tissue plasminogen activator (tPA) signal peptide were added to the modified MMP to generate tPA-MMP, followed by addition of two restriction enzyme sites to both ends to improve the translation, secretion, and subcloning into a suitable vector. The modified tPA-MMP was sent out for synthesis. Reanalysis of the modified sequence using Phobius revealed that the addition of the signal peptide to generate the tPA-MMP ORF customized for human codon usage shifted its predicted sub-cellular localization to a secreted protein (Figure 1).

\section{Construction and Transient Expression of tPA-MMP in a Secreted Form}

As described, the tPA-MMP was provided with a heterologous signal peptide to facilitate expression and secretion by mammalian cells. The synthetic tPA-MMP (Figure 1A) was placed under the transcriptional control of the Elongation Factor 1 alpha $(\mathrm{EF} 1 \alpha)$ promoter, followed by the bovine growth hormone polyadenylation signal to obtain an EF1 $\alpha$-tPA-MMP expression cassette. The expression cassette was integrated into a mammalian expression vector (pEF1 $\alpha$-tPA-MMP) and into a lentiviral vector (pEF1 $\alpha$-tPA-MMP-CMV-EGFP:T2A:Puro) (Figure 2A). pEF1 $\alpha$-tPA-MMP transiently transfected HEK293 cells and pEF1 $\alpha$-tPA-MMP-CMV-EGFP:T2A:Puro transduced HEK 293 T cells secreted the tPA-MMP peptide (Figures 2B,C).

\section{tPA-MMP Peptide Expressed by Mammalian Cells Is Glycosylated}

tPA-MMP products extracted and secreted from mammalian cells migrated with a lower mobility than expected (Figure 2B), indicating a molecular weight higher than $35 \mathrm{kDa}(\sim 43 \mathrm{kDa})$, which is in contrast with what was previously published (34). In fact, MMP was originally called the " $M$. paratuberculosis 35 $\mathrm{kDa}$ major membrane protein" (34). Based on this observation, a possible glycosylation of MMP expressed in mammalian cells was considered. Moreover, tPA-MMP detected in the cell extract had two bands: One could be the glycosylated fraction, and the second, the un-glycosylated fraction of the protein (Figure 2B). The tPA-MMP detected in the secreted peptide fraction showed just a single band of $\sim 43 \mathrm{kDa}$, attributable to a glycosylated protein form of MMP, in agreement with the fact that secreted proteins in mammalian cells are post-translationally modified, in this case, glycosylated. To explore this possibility, the MMP peptide-modified sequence was analyzed with different glycosylation site prediction programs (Glyco EP, http://www.imtech.res.in/cgibin/glycoep/ glyechk?job=932\&tim=45; NetGlyc 1.0, http://www.cbs.dtu.dk/ services/NetNGlyc/; Protter, http://wlab.ethz.ch/protter/\#). All three of the analysis programs yielded highly concordant results. Three potential N-linked and two O-linked glycosylation sites were predicted (Figure 3A). Among all these predicted sites, the first two $\mathrm{N}$-linked glycosylation sites showed the higher scores in terms of prediction. This prediction was validated by treating the secreted tPA-MMP with PNGase F, an amidase that cleaves between the innermost GlcNAc and asparagine residues of high mannose. As shown in Figure 3B, PNGase $\mathrm{F}$ treatment of tPA-MMP shifted its molecular size down to $\sim 35 \mathrm{kDa}$. These data were further corroborated by mutating the five potentially glycosylated residues of tPAMMP (tPA-MMP-5mut), where the three asparagines and the two threonines were substituted with glutamine in order to eliminate all potential glycosylation sites (Figure 4A). Secreted tPA-MMP-5mut showed the same mobility of secreted, PNGase F-treated tPA-MMP (Figure 4B). Therefore, it was hypothesized that there is no O-linked glycosylation and that tPA-MMP N-linked glycosylation is only related to the first two asparagine residues, affirming the higher prediction scores of the first two predicted $\mathrm{N}$-linked glycosylation sites in respect to the third predicted site. This hypothesis was further validated by generating a second tPA-MMP mutant, tPAMMP-2mut, in which only the first two asparagine residues were substituted with glutamine (Supplementary Figure 3). In fact, secreted tPA-MMP-2mut, tPA-MMP-5mut, and PNGase Ftreated tPA-MMP showed identical patterns of electrophoretic mobility (Figure 4C).

\section{Expression Levels of tPA-MMP-2mut and tPA-MMP-5mut Are Lower Than that of tPA-MMP}

Although tPA-MMP-2mut, tPA-MMP-5mut, and tPA-MMP were expressed, quantitative differences were observed in the amount of secreted product. Therefore, all three constructs were cloned under the control of two different promoters, EF1 $\alpha$ and CMV, to exclude a different promoter contribution in terms of transcription. Intracellular protein production was analyzed to assess the impact of protein glycosylation on protein secretion. As shown in Figure 5, less of the tPA-MMP-5mut of the intracellularly expressed and secreted products were expressed in comparison with tPA-MMP2 mut and tPA-MMP expressed and secreted products. Since the tPA-MMP-5mut is un-glycosylated like tPA-MMP-2mut, and the tPA-MMP has similar intracellular expression and secretion levels compared to tPA-MMP-2mut, the quantitative expression difference could be attributed to tPA-MMP-5mut ORF mutations that might affect tPA-MMP-5mut transcription stability. Studies were conducted to explore this possibility. Similar data were obtained using the two different transcription 


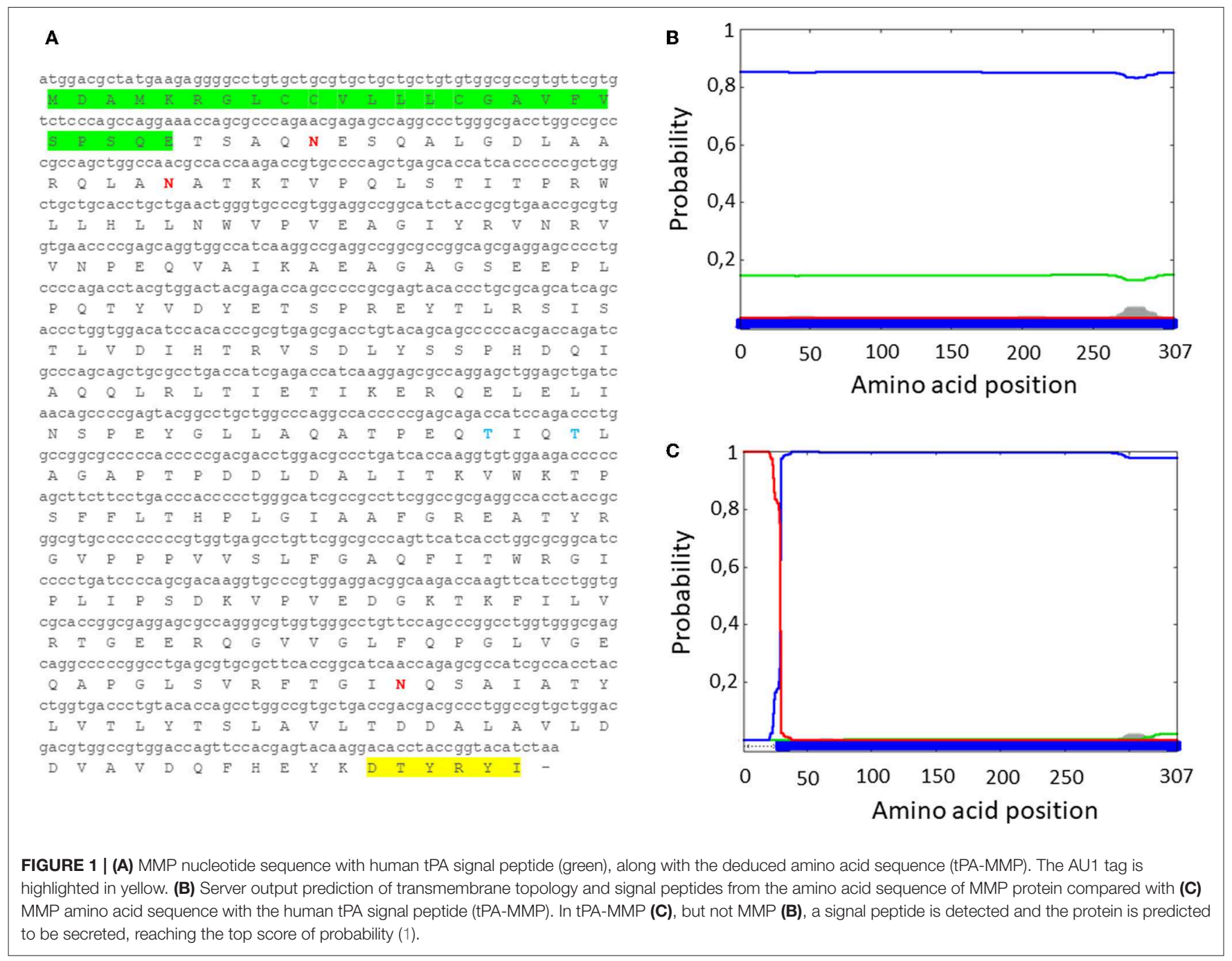

promoters on the three different tPA-MMP ORFs (Figure 5), thus excluding transcriptional differences as an explanation for the observed differences in the level of expression of products. Expression appeared to be slightly more efficient under the control of the CMV promoter in the transient transfection assay.

\section{Comparison of the CD4 and CD8 T Cell Proliferative Response to APC Pulsed With eMMP, tPA-MMP, tPA-MMP-2mut, tPA-MMP-5mut Peptides-Stimulated Cells}

Development of an MMP expression cassette for insertion into a mammalian expression vectors was successful. The next series of studies were conducted to establish that the modified expressed products retained the immunogenic and functional activities of the native peptide expressed in E. coli, eMMP. The ex vivo platform developed to study the immune response to candidate vaccine antigens was used in conjunction with a bacterium viability assay to compare the immune response of the modified tPA-MMP products with the immune response elicited with eMMP (22). The initial studies conducted during the development of the assays revealed that the flow cytometric assay could be used to phenotype the lymphocytes proliferating in response to stimulation with APC [conventional dendritic cells (DC) present in PBMC depleted of monocytes and monocyte derived DC] pulsed with live bacteria or peptides. For study of the recall and CTL response, one round of stimulation with antigen was sufficient to elicit a proliferative response for phenotyping following 6 days of culture and for analysis of their functional activity using the bacterium viability assay. Two rounds of stimulation with APC pulsed with antigen were needed to expand the culture of proliferating antigen specific $\mathrm{T}$ cells for flow cytometry and for analysis of their functional activity using the bacterium viability assay. This time interval provided sufficient time to generate autologous monocyte-derived macrophages for use as infected target cells. As outlined in section Materials and Methods, half the respective preparations of control and stimulated cells were used for phenotyping, and the other half were used in the killing assay. 

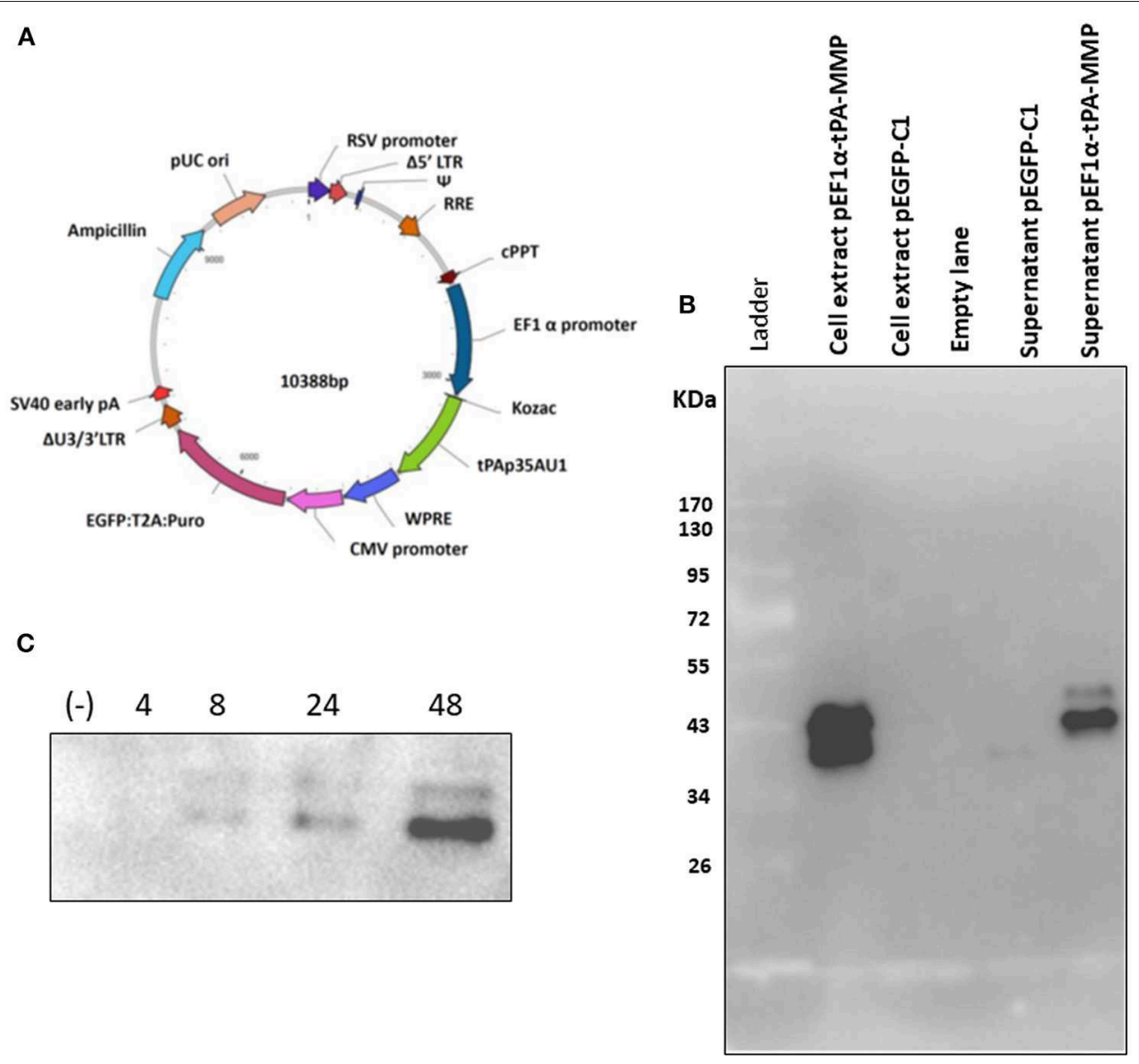

FIGURE 2 | (A) Diagram of a third-generation lentiviral transfer vector delivering tPA-MMP ORF (tPAp35AU1, green) expression cassette and GFP/Puromycin reporter gene/selectable marker (EGFP:T2A:Puro, purple) expression cassette. Different genetic elements depicted within the construct from nucleotide position 0 are: RSV promoter (blue violet); $\triangle 5^{\prime}$ LTR (brown); $\Psi$ (medium blue); RRE (chocolate); CPPT (brown); EF1 $\alpha$ (navy); WPRE (royal blue); CMV promoter (orchid); $\Delta \mathrm{U} 3 / 3^{\prime}$ LTR (sienna); Sv40 early pA (red); Ampicillin (turquoise); pUC ori (dark salmon). (B) Western immunoblot of pEF1 $\alpha$-tPA-MMP and pEGFP-C1 transfected HEK 293T cell extracts and supernatant. Lanes with cell extract were loaded with $20 \mu \mathrm{g}$ of total protein, whereas the lanes with supernatant were loaded with $20 \mu \mathrm{l}$ of serum-free medium incubated for $48 \mathrm{~h}$ with transfected cells. Cells transfected with pEGFPC-1 served as negative controls (Mock). (C) Western immunoblot of pEF1a-tPA-MMP-CMV-EGFP:T2A:Puro-transduced and Puromicin-selected HKB-11 cells, supernatant collected at 4, 8, 24, and $48 \mathrm{~h}$ incubation. In each lane, $15 \mu \mathrm{l}$ of conditioned serum-free medium was loaded. The negative control (-) was established with a similar lentiviral vector delivering only GFP (pEF1 $\alpha$-iresGFP).

The latter cell preparations were added to the cultures of autologous infected macrophages for $24 \mathrm{~h}$. Then, all the cells in the respective cultures were collected and lysed to isolate bacterial DNA for viability analysis.

\section{Flow Cytometric Analysis of the Proliferative Response}

The flow cytometric assay used in this study was developed and validated in previous studies. It was designed to more accurately identify and phenotype antigen specific CD4 and CD8 T cells proliferating in response to $\operatorname{Ag}$ stimulation $(22,30)$. To develop the assay, a fluorescent vital dye (hydroethidine) was used to identify all cells present in a culture of PBMC stimulated with concanavalin A. Based on side vs. forward light scatter (SSC vs. FSC), activated proliferating cells could be distinguished from unactivated (resting) cells based on an increase in size of activated/stimulated cells. The populations could be distinguished from each other for further analysis by placing electronic gates on the populations and adding an artificial color to them to distinguish the two populations (e.g., coloring unstimulated cells orange and stimulated cells blue). When hydroethidine labeled cells were mixed with a preparation of unstimulated PBMC, the two populations could be distinguished from each other based on fluorescence (hydroethidine labeled cells fluoresce in the red Fl-2 channel). Unstimulated cells in both populations exhibited the same pattern of color coding, distinguishing them from stimulated cells coded with a different color. When the mixed populations were labeled with a monoclonal antibody (mAb) specific for CD45R0, a memory $\mathrm{T}$ cell marker, expressed on stimulated and unstimulated cells, unstimulated CD45R0 positive cells in both populations could be distinguished from the stimulated population based on difference in color using FL2 vs. FL1. When the mixed populations of cells were labeled with a mAb 


\section{A}

atgaccagcgcccagaacgagagccaggccetgggegacctggecgccegccagctggco

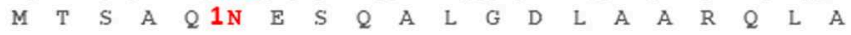
aacgccaccaagaccgtgccccagctgagcaccatcacccccgctggctgctgcacctg

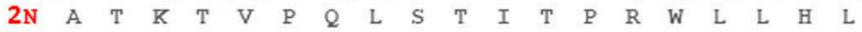
ctgaactgggtgccegtggaggccggcatctaccgcgtgaaccgcgtggtgaaccecgag $\begin{array}{lllllllllllllllllllll}\text { L } & N & \text { W } & \text { V } & \text { P } & \text { V } & \text { E } & \text { A } & G & \text { I } & Y & \text { R } & \text { V } & \text { N } & R & \text { V } & \text { V } & \text { N } & \text { P } & \text { E }\end{array}$ caggtggccatcaaggcegaggecggcgecggcagcgaggagccectgccccagacctac $\begin{array}{llllllllllllllllllll}Q & \text { V } & A & \text { I } & \text { K } & \text { A } & \text { E } & \text { A } & G & \text { A } & G & \text { S } & \text { E } & \text { E } & \text { P } & \text { L } & \text { P } & \text { Q } & \text { T } & \text { Y }\end{array}$ gtggactacgagaccagccccoggagtacaccetgcgcagcatcagcaccetggtggac $\begin{array}{llllllllllllllllllll}\mathrm{V} & \mathrm{D} & \mathrm{Y} & \mathrm{E} & \mathrm{T} & \mathrm{S} & \mathrm{P} & \mathrm{R} & \mathrm{E} & \mathrm{Y} & \mathrm{T} & \mathrm{L} & \mathrm{R} & \mathrm{S} & \mathrm{I} & \mathrm{S} & \mathrm{T} & \mathrm{L} & \mathrm{V} & \mathrm{D}\end{array}$ atccacacccgcgtgagcgacetgtacagcagccccacgaccagatcgcccagcagctg

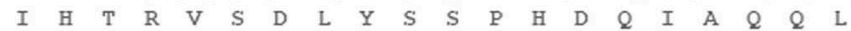
cgcctgaccatcgagaccatcaaggagcgccaggagctggagctgatcaacagccecgag $\begin{array}{llllllllllllllllllllllllllll}R & L & T & I & E & T & I & K & E & R & Q & E & L & E & L & I & N & S & P & E\end{array}$ tacggcetgetggcccaggecaccccogagcagaccatccagaccetggceggegeccec $\begin{array}{lllllllllllllllllllll}Y & G & L & L & A & Q & A & T & P & E & Q & 1 T & I & Q & 2 T & L & A & G & A & P\end{array}$ accccgacgacctggacgccetgatcaccaaggtgtggaagaccccagcttcttcctg $\begin{array}{lllllllllllllllllllll}T & P & D & D & L & D & A & L & I & T & K & V & W & K & T & P & S & F & F & L\end{array}$ acccaccectgggcatcgecgecttcggecgegaggecacctaccgeggegtgececcc

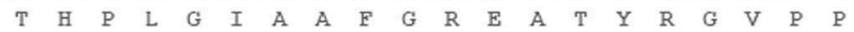
cccgtggtgagcetgttcggegcccagttcatcacctggcgeggcatccectgatccec

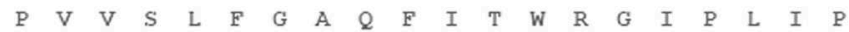
agcgacaaggtgccegtggaggacggcaagaccaagttcatcctggtgegcaccggcgag $\begin{array}{lllllllllllllllllllllllllll}S & D & K & V & P & V & E & D & G & K & T & K & F & I & L & V & R & T & G & E\end{array}$ gagcgecagggcgtggtgggectgttccagcceggcetggtgggegagcaggcceccggc $\begin{array}{llllllllllllllllllllll} & \mathrm{R} & \mathrm{R} & \mathrm{Q} & \mathrm{G} & \mathrm{V} & \mathrm{V} & \mathrm{G} & \mathrm{L} & \mathrm{F} & \mathrm{Q} & \mathrm{P} & \mathrm{G} & \mathrm{L} & \mathrm{V} & \mathrm{G} & \mathrm{E} & \mathrm{Q} & \mathrm{A} & \mathrm{P} & G\end{array}$ ctgagcgtgcgcttcaccggcatcaaccagagcgccatcgccacctacctggtgaccetg

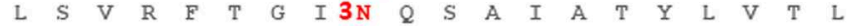
tacaccagcetggcegtgctgaccgacgacgecetggecgtgctggacgacgtggecgtg

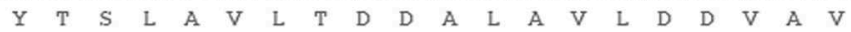
gaccagttccacgagtacaagtaa

$\begin{array}{llllllllll}D & Q & F & \text { H } & E & Y & K & -\end{array}$

N: potential N-linked glycosylation site

$\mathrm{T}$ : potential O-linked glycosylation site

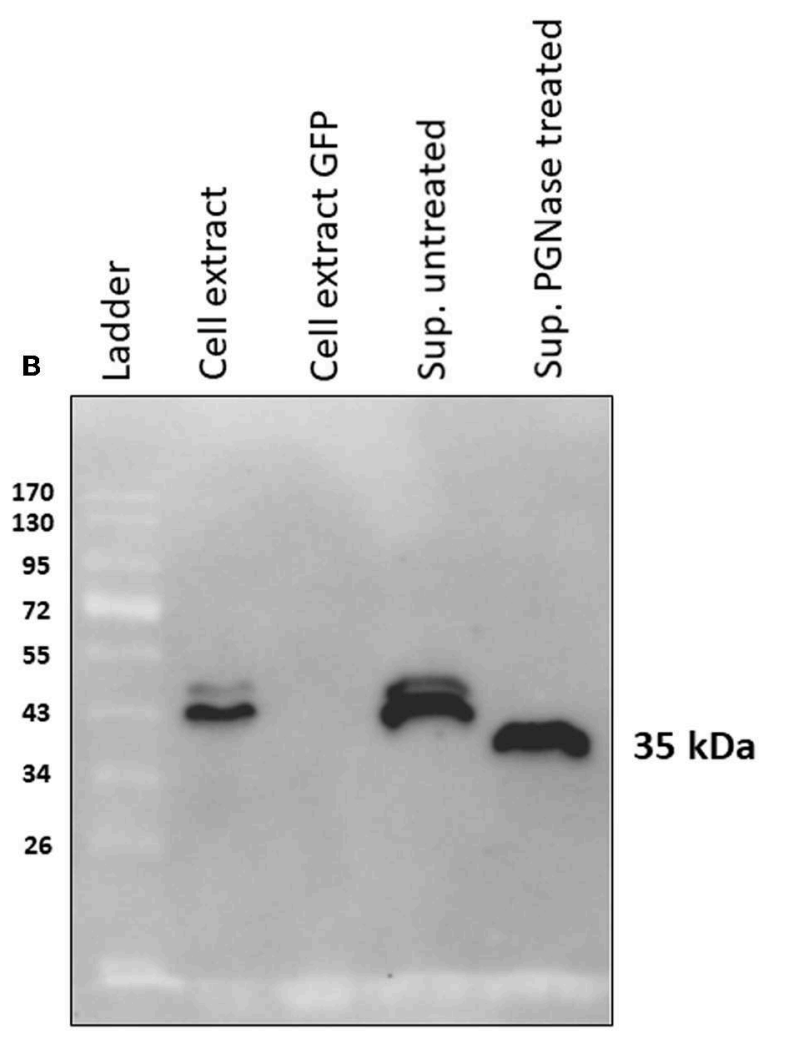

FIGURE 3 | (A) MMP N-linked (1N, 2N, and 3N in red) and O-linked (1T and 2T in blue) predicted glycosylation sites. (B) Western immunoblot of tPA-MMP secreted protein treated (Sup PNGase treated) or untreated (Sup untreated) with PGNase F. Cell extracts from pEF1 $\alpha$-tPA-MMP (Cell extract) and pEGFP-C1 (Cell extract GFP) transfected HEK 293T cells were used as positive and negative controls, respectively.

only expressed on stimulated cells (e.g., ACT1), unstimulated cells that did not express ACT1 could be distinguished from stimulated cells that expressed ACT1 (30). Further studies demonstrated that Ag specific memory CD4 and CD8 T cells proliferating in response to Ag stimulation ex vivo, could be distinguished from unstimulated memory $\mathrm{T}$ cells based on the use of selective gating alone to distinguish activated cells based on size and expression of CD45R0 and molecules only expressed on activated $\mathrm{T}$ cells. As reported here, a single selective gate was placed on cells displayed in SSC vs. FSC to isolate the population for analysis. A second selective gate was placed on either $\mathrm{CD} 4$ or $\mathrm{CD} 8 \mathrm{~T}$ cell populations displayed in FSC vs. CD4 or CD8. Both isolated populations were then displayed in FSC vs. CD45R0 for analysis. A box gate was placed on the proportion memory cells showing an increase in size based on FSC (Supplementary Figure 4) (22). This corresponded to the activated cells identified using the initial color coding and gating strategy (30). The proportion of cells present in this gate in preparation of cells from unstimulated cultures were compared with the proportion of cells present in stimulated cultures to determine the increase in the proportion of cells associated with $\mathrm{Ag}$ stimulation. Previous studies had documented that these cells were the only cells positive for molecules only expressed on activated cells. Analysis of mdPBMC pulsed with the positive control eMMP showed that the activation and proliferative responses of the memory CD4 and CD8 T cells were consistent with responses obtained in previous experiments using two rounds of stimulation of mdPBMC with antigen-pulsed APC. Comparison of the proliferative responses of CD4 and CD8 T cells elicited by eMMP with responses elicited by tPA-MMP and tPA-MMP2 mut showed that the responses were similar. In contrast, the proliferative response elicited by tPA-MMP-5mut was limited as illustrated with a representative set of flow cytometric profiles obtained from one of three duplicate sets of experiments conducted with one of the three steers used in the study (Figure 6). Therefore, tPA-MMP-5mut was excluded from further analysis. 


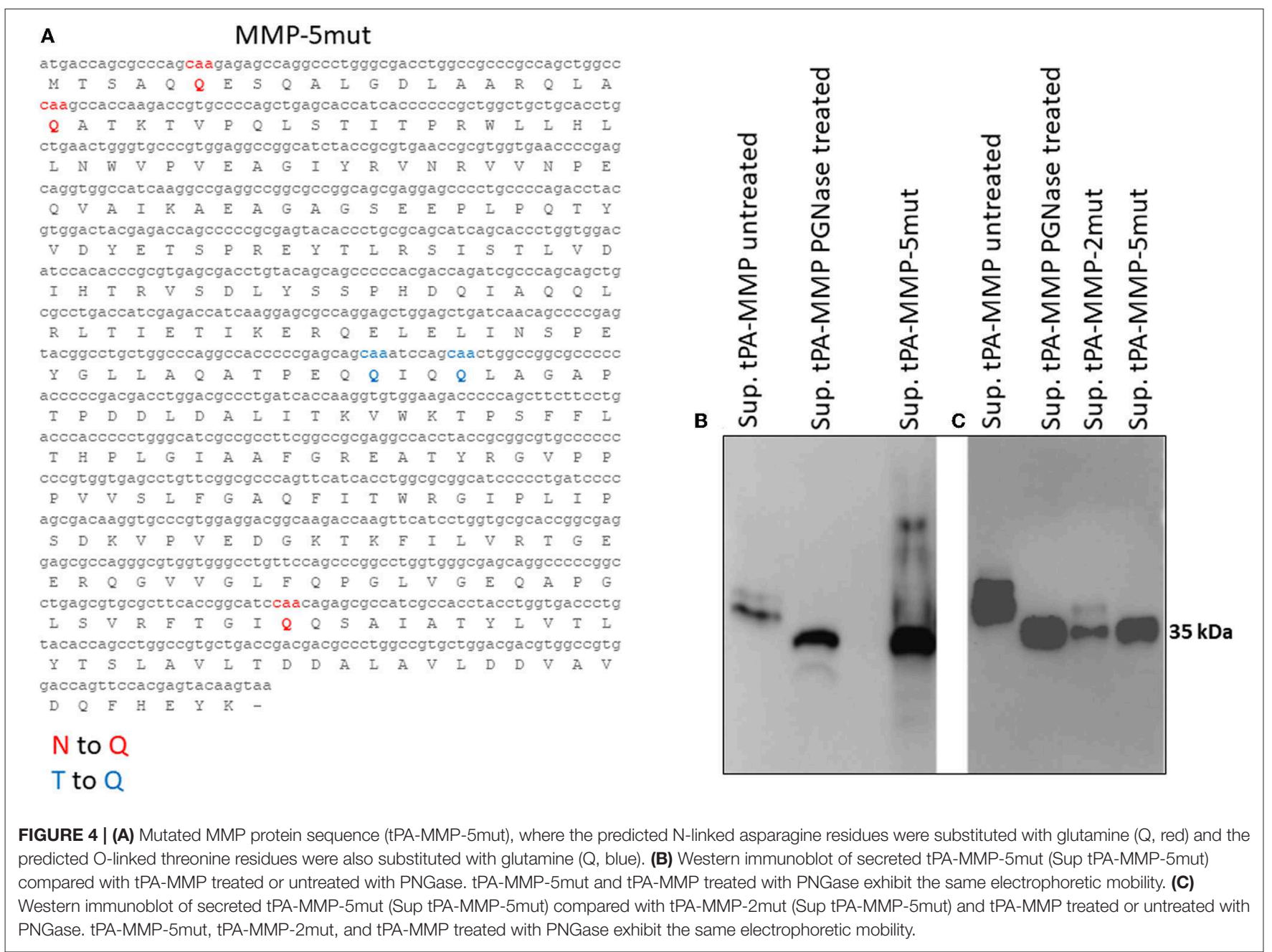

\section{Comparison of CTL Activity}

As illustrated in Figure 7A, a standard curve was generated with DNA from the single-copy gene, F57, for comparison of the proportion of viable bacteria present in each preparation of Map isolated from each cell preparation. Because blocking of F57 DNA by PMA is incomplete, a second control preparation was made from macrophages infected with a known concentration of live and dead bacteria to establish where the concentrations of live and dead bacteria will fall on the standard curve. This control was also used to show the sensitivity of the assay to determine the relative proportion of live bacteria present in each culture of infected target cells at the time of DNA isolation. Comparison of live bacteria isolated from control-infected macrophages immediately after infection with live bacteria isolated at $24 \mathrm{~h}$ after infection (identical to the time infected macrophages were incubated with unstimulated and antigen stimulated mdPBMC) showed that there was limited loss of live bacteria during the 24-h incubation period. There was also limited loss of live bacteria in infected macrophage preparations incubated with unstimulated mdPBMC. In contrast, there was a clear loss of live bacteria in preparations of infected macrophages incubated with eMMP, tPA-MMP, and tPA-MMP-2mut. Comparison of the CTL activity of CD8 $\mathrm{T}$ cells from the three steers that proliferated in response to stimulation with eMMP, tPA-MMP, and tPA-MMP2mut showed that the CTL activity of CD8 T cells stimulated with tPA-MMP-2mut was consistently better than the CTL activity of CD8 T cells stimulated with tPA-MMP (Figure 7B). However, both CTL responses were slightly less than the response elicited with eMMP.

\section{DISCUSSION}

Efforts to develop vaccines against mycobacterial pathogens have been impeded by the lack of understanding the mechanisms used by the pathogens to establish a persistent infection. This occurs concurrently with the development of humoral and cellmediated responses to the mycobacteria that are able to delay development of clinical disease. In humans, the immune response that develops against $M t b$ is sufficient to maintain immune control for a lifetime in most exposed subjects. Clinical disease occurs in $\sim 10 \%$ of individuals persistently infected with $M t b$, and is associated with impairment of immune function (35). This may also occur in response to infection with Map in humans $(3-5,36)$. Studies in cattle have shown that exposure 


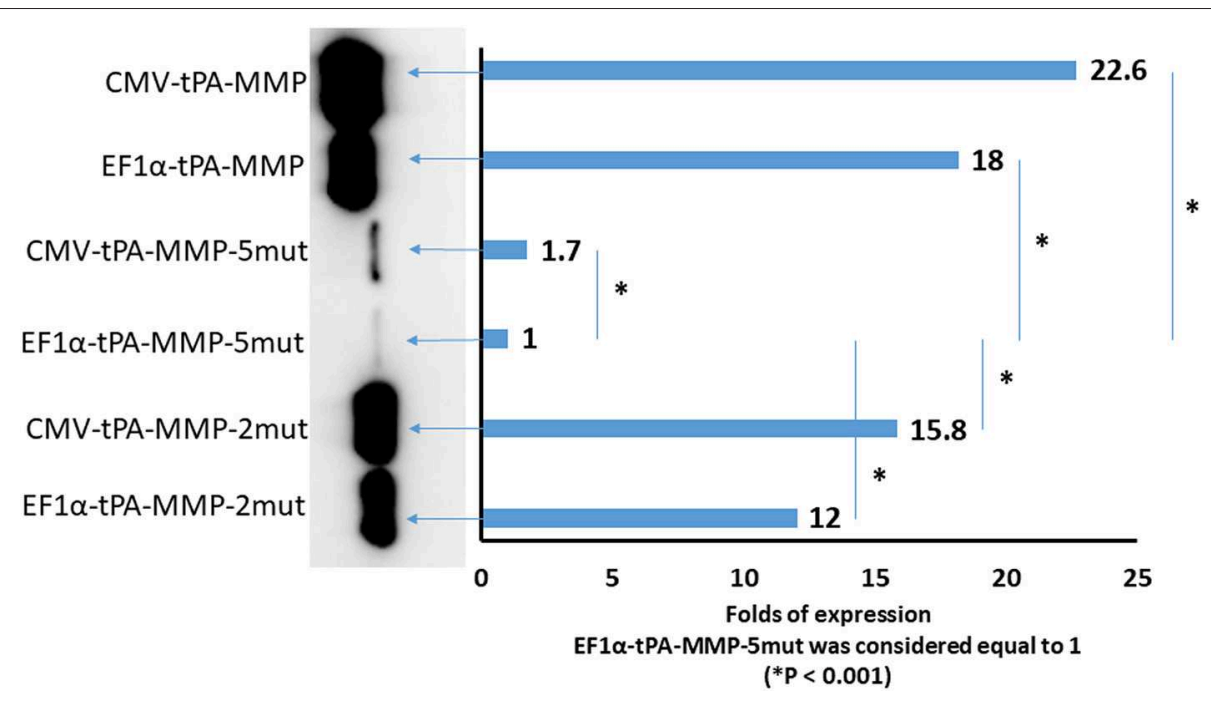

FIGURE 5 | Quantitative Western immunoblot of serum-free medium containing secreted tPA-MMP-5mut, tPA-MMP-2mut, and tPA-MMP from pCMV-tPA-MMP-5mut, pEF1 $\alpha$-tPA-MMP-5mut, pCMV-tPA-MMP-2mut, pEF1 $\alpha$-tPA-MMP-2mut, pCMV-tPA-MMP, and pEF1 $\alpha$-tPA-MMP transfected HEK 293T cells at $48 \mathrm{~h}$ post transfection. Each lane was loaded with $15 \mu \mathrm{l}$ of serum-free medium supernatant. The same number of HEK $293 \mathrm{~T}$ cells were transfected with the same amount of each DNA plasmid with the same efficiency of transfection (100\%), as determined by co-transfection with pEGFP-C1. Band intensity was quantified using densitometry (ChemiDoc; MPIMAGING SYSTEM, LAB SOFTWARE, BioRad), and displayed using a bar graph. Data were normalized as folds of increased secretion, where pEF1 $\alpha$-tPA-MMP-5mut signal was considered equal to 1. The experiment was repeated three times, and statistical significance $(P<0.001)$ was assessed using a Student's t-test and one-way ANOVA.

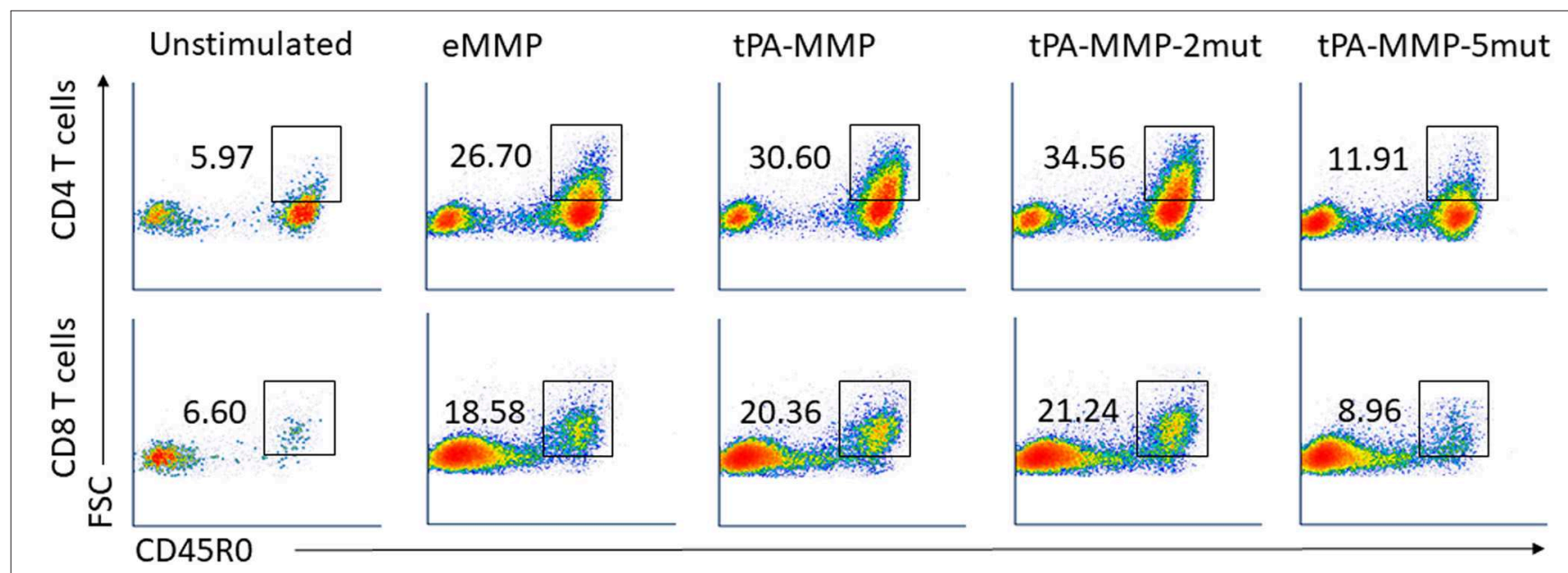

FIGURE 6 | Representative FC profiles comparing CD4 and CD8 T cell proliferation in response to peptides. FC dot-plots represent the frequency of activated memory CD4 (first row) and CD8 (second row) T cells in unstimulated or eMMP, tPA-MMP, tPA-MMP-2mut, and tPA-MMP-5mut-stimulated mdPBMC. The profiles are representative of replicates of the FC data obtained from the three steers used in the study.

leads to development of a latency that varies in duration, with a breakdown in protective immunity occurring two or more years post exposure. The immune response during the early stages of infection is resilient and not readily disrupted by use of immunosuppressive agents like dexamethasone or depletion of CD4 T cells at the time exposure (37). The response is sufficient to suppress bacterial replication to the extent that it is difficult to detect the presence of bacteria in any tissue (17). Eventually, however, for yet to be explained reasons, protective immunity is disrupted and clinical disease develops.
Of importance to the development of a vaccine against Map and other mycobacterial pathogens, this evasion tactic is lost when relA is disrupted. This was first demonstrated by Dahl et al. using a mouse model with a relA $M t b$ deletion mutant. The mutant was unable to establish a persistent infection (20). Studies with Map revealed that deletion of relA had the same effect. Infection with the mutant was cleared (38). Development of a flow cytometric assay and a bacterium viability assay to replace the $\mathrm{cfu}$ assay facilitated characterization of the phenotype and functional activity of CD4 and CD8 T cells proliferating 
A

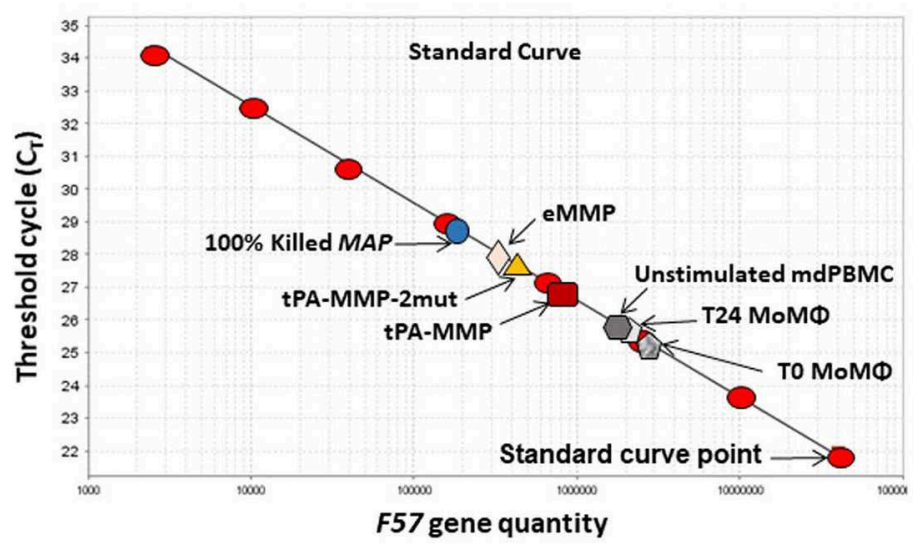

○: Standard curve $\bigcirc$ : Killed MAP control

$\checkmark$ : Infected MOMФ lysed after 3 hours of infection (TO)

$\checkmark$ : Infected MoM $\Phi$ co-cultured 24 hrs without $\mathrm{T}$ cells

$\square:$ Infected MoM $\Phi$ co-cultured 24 hrs with unstimulated T cells (Control)

$\diamond:$ Infected MoMФ co-cultured 24 hrs with eMMP stimulated T cells

$\triangle$ : Infected MOMФ co-cultured 24 hrs with tPA-MMP-2mut stimulated T cells

: Infected MoMФ co-cultured 24 hrs with tPA-MMP stimulated T cells
B

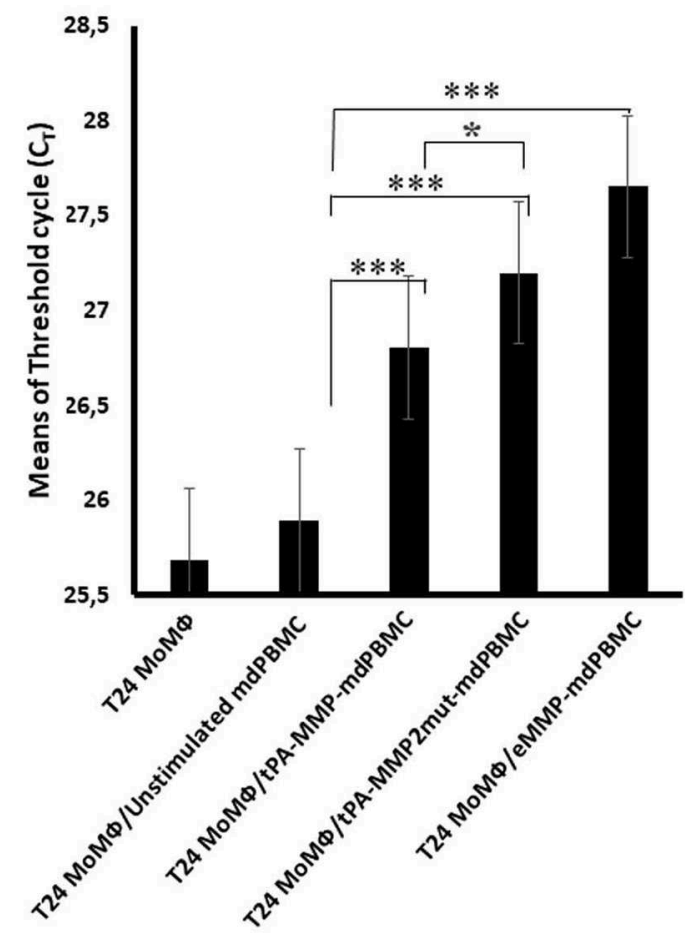

FIGURE 7 | Intracellular Map PMA-QPCR viability assay. (A) Graphical representation of real-time PCR data for Map intracellular killing to determine the $\mathrm{C}_{\mathrm{T}}$ values measured for amplification of the Map F57 target gene. $\mathrm{C}_{T}$ values represent average of duplicate preparations of DNA isolated from pure Map (8 red oval points), Map viability control (blue circle), Map-infected MoM $\Phi$ lysed after $3 \mathrm{~h}$ of infection (gray pentagon), Map-infected MoM $\Phi$ lysed after $24 \mathrm{~h}$ of infection (light gray pentagon), cell mixture lysed after $24 \mathrm{~h}$ of co-culturing of Map-infected MoM $\Phi$ with unstimulated mdPBMC (dark gray hexagon), cell mixture lysed after 24-h co-culture of Map-infected MoM $\Phi$ with mdPBMC stimulated twice with tPA-MMP (dark red rectangle), tPA-MMP-5mut (gold triangle), or eMMP (pink diamond). (B) Summary of three biological replicate experiments performed in duplicate from each of the three steers comparing the killing activity following stimulation with the different MMP peptides relative to controls. ${ }^{\star} P<0.05 ;{ }^{* \star \star} P<0.001$.

during the recall response following stimulation with the Map relA mutant. Analysis revealed that clearance was attributable to development of CD8 CTL with the ability to kill intracellular bacteria (22). Analysis of the response led to the discovery that a $35-\mathrm{kDa}$ membrane-associated peptide, MMP, is the target of the CTL response (22). Vaccination with a replicate of the peptide expressed in E. coli, eMMP, elicited a CTL response equivalent to the response elicited by the $\Delta M a p / r e l A$ mutant, suggesting that it might be possible to develop a peptide-based vaccine for Ptb. Analysis of the immune response to the peptide revealed a previously unrecognized feature of the response essential for eliciting CTL. Development of CD8 CTL only occurred if CD4 and CD8 $\mathrm{T}$ cells recognize their respective epitopes presented by APC at the same time. Using the ex vivo test platform, examination of the CTL response to stimulation with APC pulsed with MMP revealed that the CTL response was blocked in the presence of antibody to either MHC I or MHC II molecules (in review). These results showed that development of a peptidebased vaccine with eMMP would require retention of epitopes in the peptide that would be processed and presented in the context of MHC I and II molecules. This is a new salient observation that may be relevant for development of peptide-based vaccines not only for Map but also for other pathogens.
The first choice for a vector-based vaccine was the use of nanoparticles. Trial experiments with a well-characterized nanoparticle revealed that an equivalent CTL response to MMP could be elicited ex vivo with MMP alone or incorporated in a nanoparticle vector (24). Unfortunately, attempts to standardize a method of production of a nanoparticle vectored MMP vaccine for field use demonstrated that it was not possible to make a product with reliable activity, indicating that other approaches needed to be explored for the development of an MMP-based vaccine.

Extensive studies have been conducted to develop and test viral vectors for delivery of vaccines [reviewed in (39, 40)]. There has been one attempt to develop a virusvectored vaccine for Map (14). Methods were unavailable to analyze the functional activity of the expressed products. To explore the potential of developing a virus-vectored vaccine for MMP, information from ongoing studies revealed that the first step would require development of an expression cassette for insertion and testing of available viral vectors for delivery of MMP as a vaccine. Of critical importance, studies demonstrated any modifications of the native sequence of the gene encoding MMP must not alter the immunogenic properties of the expressed peptide. Antigen processing of 
any modified expressed copy of MMP by APC must lead to expression of the same epitopes in the context of MHC I and II molecules (in review). Although extensive information is available on the use of bacteria to express mammalian proteins in bacteria, information is still limited on expression of mammalian proteins through bacterial secretory pathways. The main obstacle for both viral and DNA vector-based vaccines delivering bacterial antigens is maintenance of antigen authenticity when expressed by mammalian cells. In contrast to mammalian cells, proteins expressed by bacteria do not undergo post-translational modification. Consequentially, modification for expression in mammalian cells could negatively impact peptide immunogenicity. Therefore, the design of a cassette for use in expression of bacterial proteins in mammalian expression vectors needs to be taken into consideration. As reported here, the first step in accomplishing this objective was conducted on the premise that modification of the native gene sequence encoding MMP for expression in mammalian cells, specifically human derived cell lines, would yield an expressed product with the same immunogenic activity as the native molecule expressed by MAP2121c. Proof of this premise would not be known until a modified sequence was developed and used to express a product for analysis of its immunogenic properties.

In silico analysis of the MMP sequence was conducted to predict the protein topology when expressed in mammalian cells. Although previous studies provided data indicating MMP is localized on the surface in complex with another peptide $(23,29)$, it was surprising to find that the peptide did not contain a canonical signal peptide, transmembrane domain, or a GPI anchor to sort and link MMP to the bacterial cell surface. In fact, the in silico analysis predicted localization of MMP in the cytoplasm of transfected or transduced mammalian cells. However, the finding is not unprecedented. Similar observations have been obtained in the study of other mycobacteria $(41,42)$.

Protein expression levels are closely related to genetic sequences, which are often similar but never identical between species of organisms. Comparative studies have revealed the use of two to six different synonymous DNA triplets to encode the same amino acid with some of the codons used more frequently than others, a phenomenon defined as codon usage bias, which is directly related to gene expression efficiency. This must be considered when modifying codon usage for expression of recombinant proteins by different species, in order to obviate codon usage differences and maximize efficiency of expression (43-45). In this study, MMP ORF codon usage was modified with the aid of the Java Codon Adaptation Tool (JCat) for expression of MMP in mammalian cells. The adapted MMP ORF sequence was modified further to include a mammalian signal peptide sequence to facilitate efficient intracellular expression and extracellular secretion. A third-generation, replication-incompetent pEF1 $\alpha$-tPA-MMPCMV-EGFP:T2A:Puro lentiviral vector was used to generate a recombinant lentivirus tPA-MMP expression cassette. Initial use of the cassette demonstrated that it could be used to successfully transduce different cell lines and primary cell cultures (data not shown). Particularly, we generated stable MMP lentivirus transduced human cell lines constitutively secreting tPA-MMP, tPA-MMP-2mut, and tPA-MMP-5mut for ex vivo immunization studies. We took advantage of the ability to culture the transduced cell lines in serum-free medium to produce supernatants containing the three variants of tPA-MMP almost free of non-specific proteins for use in analysis of its immunogenic activity.

SDS-PAGE and Western blot analysis of the secreted products revealed that they exhibited a slightly higher molecular weight than the expected $\sim 35 \mathrm{kDa}$ of the native MMP. In silico examination of the modified amino acid sequence of tPA-MMP using different software programs revealed that some amino acids that might be glycosylated, explaining the unexpected difference in the pattern of electrophoretic migration. To explore this possibility, asparagine residues in tPA-MMP predicted to be potential sites for $\mathrm{N}$-glycosylation were substituted with glutamine, a structurally similar amino acid that is not a target for glycosylation or fucosilation. In addition, supernatants containing the tPA-MMP variants were digested with PNGase F, a deglycosylation enzyme. Both manipulations of the modified tPA-MMP confirmed that $\mathrm{N}$ linked glycosylation occurred when the expression vector was transfected or transduced into mammalian cells. Both manipulations yielded a product with the expected molecular weight of native MMP as detected by its pattern of migration in SDS-PAGE.

Following physical characterization of the modified forms of tPA-MMP, it was possible to finally determine if the modifications of MMP for expression in a mammalian cell altered the capacity of MMP to elicit CTL activity essential for use of MMP in a peptide-based vaccine. As reported, the use of the ex vivo platform and bacterium viability assay facilitated analysis of the proliferative and functional activity of tPA-MMP and the mutants in comparison with MMP expressed in E. coli (eMMP). Comparison of the proliferative responses revealed that stimulation with APC pulsed with eMMP, tPA-MMP, and the tPA-MMP-2mut yielded similar proliferative responses. Stimulation with tPA-MMP-5mut yielded minimal proliferation, suggesting that the exchange of asparagine with glutamine affected the immunogenic characteristics of the peptide. Based on this finding, tPA-MMP-5mut was excluded from further testing. Additional comparisons of the capacity of the expressed, modified tPA-MMPs revealed modest difference in the capacity of tPA-MMP and tPAMMP-2mut to elicit CTL response. The findings suggest that both tPA-MMP and tPA-MMP-2mut are suitable candidates for use in a virus-vectored vaccine for Map. Further studies are now warranted to use the shuttle vector to develop virus vectors containing tPA-MMP or tPA-MMP-2mut to test for efficacy.

\section{DATA AVAILABILITY STATEMENT}

All datasets generated for this study are included in the article/Supplementary Material. 


\section{ETHICS STATEMENT}

All protocols were reviewed and approved by the Washington State University Institutional Animal Care and Use Committee (ASAFs 3360 and 04883).

\section{AUTHOR CONTRIBUTIONS}

GD conceived the experiments. VF, AM, GA, GT, FM, LR, $\mathrm{ME}$, and GD performed the experiments. JB, K-TP, VH, and SC contributed with reagents. GD, LF, and WD analyzed the data. LF edited the paper. GD and WD wrote the paper. VF and AM shared equally in the conduct of the study. All

\section{REFERENCES}

1. Manning EJ. Paratuberculosis in captive and free-ranging wildlife. Vet Clin North Am Food Anim Pract. (2011) 27:621-30. doi: 10.1016/j.cvfa.2011.07.008

2. Carta T, Alvarez J, Perez de la Lastra JM, Gortazar C. Wildlife and paratuberculosis: a review. Res Vet Sci. (2013) 94:191-7. doi: 10.1016/j.rvsc.2012.11.002

3. Naser SA, Sagramsingh SR, Naser AS, Thanigachalam S. Mycobacterium avium subspecies paratuberculosis causes Crohn's disease in some inflammatory bowel disease patients. World J Gastroenterol. (2014) 20:7403-15. doi: 10.3748/wjg.v20.i23.7403

4. Singh SV, Kumar N, Sohal JS, Singh AV, Singh PK, Agrawal ND, et al. First mass screening of the human population to estimate the bio-load of Mycobacterium avium sub-species paratuberculosis in North India. J Public Health Epidemiol. (2014) 6:20-9. doi: 10.5897/JPHE2013.0564

5. Davis WC. Why is the obvious not obvious, it is Johne's Disease (Paratuberculosis) Not Crohn's Disease. EC Gastroenterol Digest Syst. (2018) 5:752-8

6. Barkema HW, Orsel K, Nielsen SS, Koets AP, Rutten V, Bannantine JP, et al. Knowledge gaps that hamper prevention and control of Mycobacterium avium subspecies paratuberculosis infection. Transbound Emerg Dis. (2018) 65:125-48. doi: 10.1111/tbed.12723

7. Rathnaiah G, Zinniel DK, Bannantine JP, Stabel JR, Grohn YT, Collins MT, et al. Pathogenesis, molecular genetics, and genomics of Mycobacterium avium subsp. paratuberculosis, the Etiologic Agent of Johne's Disease. Front Vet Sci. (2017) 4:187. doi: 10.3389/fvets.2017.00187

8. McAloon CG, Roche S, Ritter C, Barkema HW, Whyte P, More SJ, et al. A review of paratuberculosis in dairy herds - Part 1: epidemiology. Vet J. (2019) 246:59-65. doi: 10.1016/j.tvjl.2019.01.010

9. Whittington R, Donat K, Weber MF, Kelton D, Nielsen SS, Eisenberg S, et al. Control of paratuberculosis: who, why and how. A review of 48 countries. BMC Vet Res. (2019) 15:198. doi: 10.1186/s12917-0191943-4

10. McAloon CG, Roche S, Ritter C, Barkema HW, Whyte P, More SJ, et al. A review of paratuberculosis in dairy herds - Part 2: on-farm control. Vet J. (2019) 246:54-8. doi: 10.1016/j.tvjl.2019.01.009

11. Juste RA, Alonso-Hearn M, Molina E, Geijo M, Vazquez P, Sevilla IA, et al. Signoficant reduction in bacterial shedding and improvement in milk production in dairy farms after the use of a new inactivated paratuberculosisd vaccine in a field trial. BMC Res. (2009) 2:233-6. doi: 10.1186/1756-0500-2-233

12. Keshavarz R, Mosavari N, Tadayon K, Haghkhah M. Effectiveness of an inactivated paratuberculosis vaccine in Iranian sheep flocks using the Mycobacterium avium subsp paratuberculosis 316F strain. Iran J Microbiol. (2018) 10:117-22.

13. Kathaperumal K, Kumanan V, McDonough S, Chen L-H, Park S-U, Moreira $\mathrm{MA}$, et al. Evaluation of immune responses and protective efficacy in a goat model following immunization with a coctail of recombinant antigens and a authors participated in the review of the present version of the manuscript.

\section{FUNDING}

This work was supported by the Italian Ministry of University and Scientific Research (Italian National Grant MIUR, PRIN 2010-2011) and the WSU Monoclonal Antibody Centre.

\section{SUPPLEMENTARY MATERIAL}

The Supplementary Material for this article can be found online at: https://www.frontiersin.org/articles/10.3389/fimmu. 2019.02859/full\#supplementary-material polyprotein of Mycobacterium avium subsp. Paratuberculosis. Vaccine. (2009) 27:123-35. doi: 10.1016/j.vaccine.2008.10.019

14. Bull TJ, Vrettou C, Linedale R, McGuinnes C, Strain S, McNair J, et al. Immunity, safety and protection of an Adenovirus 5 prime-Modified Vaccinia virus Ankara boost subunit vaccine against Mycobacterium avium subspecies paratuberculosis infection in calves. Vet Res. (2014) 45:112. doi: 10.1186/s13567-014-0112-9

15. Bannantine JP, Everman JL, Rose SJ, Babrak L, Katani R, Barletta RG, et al. Evaluation of eight live attenuated vaccine candidates for protection against challenge with virulent Mycobacterium avium subspecies paratuberculosis in mice. Front Cell Infect Microbiol. (2014) 4:88. doi: 10.3389/fcimb.2014.00088

16. Bannantine JP, Hines ME II, Bermudez LE, Talaat AM, Sreevatsan S, Stabel JR, et al. A rational framework for evaluating the next generation of vaccines against Mycobacterium avium subspecies paratuberculosis. Front Cell Infect Microbiol. (2014) 4:126. doi: 10.3389/fcimb.2014.00126

17. Koo HC, Park YH, Hamilton MJ, Barrington GM, Davies CJ, Kim JB, et al. Analysis of the immune response to Mycobacterium avium subsp. paratuberculosis in experimentally infected calves. Infect Immun. (2004) 72:6870-83. doi: 10.1128/IAI.72.12.6870-6883.2004

18. Allen AJ, Park KT, Barrington GM, Lahmers KK, Abdellrazeq GS, Rihan $\mathrm{HM}$, et al. Experimental infection of a bovine model with human isolates of Mycobacterium avium subsp. paratuberculosis. Vet Immunol Immunpathol. (2011) 141:258-66. doi: 10.1016/j.vetimm.2011.03.014

19. Park KT, Dahl JL, Bannantine JP, Barletta RG, Ahn J, Allen AJ, et al. Demonstration of allelic exchange in the slow-growing bacterium Mycobacterium avium subsp. paratuberculosis, and generation of mutants with deletions at the pknG, relA, and lsr2 loci. Appl. Environ. Microbiol. (2008) 74:1687-95. doi: 10.1128/AEM.01208-07

20. Dahl JL, Kraus CN, Boshoff HIM, Doan B, Foley K, Avarbock D, et al. The role of RelMtb-mediated adaptation to stationary phase in long-term persistence of Mycobacterium tuberculosis in mice. Proc Natl Acad Sci USA. (2003) 100:10026-31. doi: 10.1073/pnas.1631248100

21. Park KT, Allen AJ, Bannantine JP, Seo KS, Hamilton MJ, Abdellrazeq GS, et al. Evaluation of two mutants of Mycobacterium avium subsp. paratuberculosis as candidates for a live attenuated vaccine for Johne's disease. Vaccine. (2011) 29:4709-19. doi: 10.1016/j.vaccine.2011.04.090

22. Abdellrazeq GS, Elnaggar MM, Bannantine JP, Park KT, Souza CD, Backer B, et al. A Mycobacterium avium subsp. paratuberculosis relA deletion mutant and a $35 \mathrm{kDa}$ major membrane protein elicit development of cytotoxic $\mathrm{T}$ lymphocytes with ability to kill intracellular bacteria. Vet Res. (2018) 49:53. doi: 10.1186/s13567-018-0549-3

23. Leite FL, Reinhardt TA, Bannantine JP, Stabel JR. Envelope protein complexes of Mycobacterium avium subsp. paratuberculosis and their antigenicity. Vet Microbiol. (2015) 175:275-85. doi: 10.1016/j.vetmic.2014.11.009

24. Abdellrazeq GS, Elnaggar MM, Bannantine JP, Schneider DA, Souza $\mathrm{CD}$, Hwang $\mathrm{J}$, et al. A peptide-based vaccine for Mycobacterium avium subspecies paratuberculosis. Vaccine. (2019) 37:2783-90. doi: 10.1016/j.vaccine.2019.04.040 
25. Donofrio G, Cavirani S, Simone T, van Santen VL. Potential of bovine herpesvirus 4 as a gene delivery vector. J Virol Methods. (2002) 101:49-61. doi: 10.1016/S0166-0934(01)00419-0

26. Tebaldi G, Williams LB, Verna AE, Macchi F, Franceschi V, Fry LM, et al. Assessment and optimization of Theileria parva sporozoite full-length p67 antigen expression in mammalian cells. PLoS Negl Trop Dis. (2017) 11:e0005803. doi: 10.1371/journal.pntd.0005803

27. Park KT, Burnett S, Davis WC. Development and characterization of a monoclonal antibody specific for bovine CD209. Vet Immunol Immunopathol. (2015) 163:216-20. doi: 10.1016/j.vetimm.2014.12.008

28. Park KT, ElNaggar MM, Abdellrazeq GS, Bannantine JP, Mack V, Fry LM, et al. Phenotype and function of CD209+ Bovine blood dendritic cells, monocyte-derived-dendritic cells and monocyte-derived macrophages. PLoS ONE. (2016) 11:e0165247. doi: 10.1371/journal.pone.0165247

29. Bannantine JP, Huntley JF, Miltner E, Stabel JR, Bermudez LE. The Mycobacterium avium subsp. paratuberculosis $35 \mathrm{kDa}$ protein plays a role in invasion of bovine epithelial cells. Microbiology. (2003) 149:2061-9. doi: 10.1099/mic.0.26323-0

30. Park KT, Seo KS, Godwin NA, Van Wie BJ, Gulbahar MY, Park YH, et al. Characterization and expression of monoclonal antibody-defined molecules on resting and activated bovine alphabeta, gammadelta $\mathrm{T}$ and NK cells. Vet Immunol Immunopathol. (2015) 168:118-30. doi: 10.1016/j.vetimm.2015.09.002

31. Park KT, Allen AJ, Davis WC. Development of a novel DNA extraction method for identification and quantification of Mycobacterium avium subsp. paratuberculosis from tissue samples by real-time PCR. J Microbiol Methods. (2014) 99:58-65. doi: 10.1016/j.mimet.2014.02.003

32. Kralik P, Nocker A, and Pavlik I. Mycobacterium avium subsp. paratuberculosis viability determination using F57 quantitative PCR in combination with propidium monoazide treatment. Int J Food Microbiol. (2010) 141 (Suppl. 1):S80-6. doi: 10.1016/j.ijfoodmicro.2010.03.018

33. Schonenbrucher $\mathrm{H}$, Abdulmawjood A, Failing K, Bulte M. New triplex real-time PCR assay for detection of Mycobacterium avium subsp. paratuberculosis in bovine feces. Appl Environ Microbiol. (2008) 74:2751-8. doi: 10.1128/AEM.02534-07

34. Banasure KD, Basagoudanavar SH, Chaudhury P, Tiwari V, Parihar NS, Goswami PP. Identification and characterization of a gene encoding a 35$\mathrm{kDa}$ protein from Mycobacterium avium subspecies paratuberculosis. FEMS Microbiol Lett. (2001) 196:195-9. doi: 10.1111/j.1574-6968.2001.tb10564.x

35. Nieuwenhuizen NE, Kaufmann SHE. Next-generation vaccines based on bacille calmette-guerin. Front Immunol. (2018) 9:121. doi: 10.3389/fimmu.2018.00121

36. Kuenstner JT, Naser S, Chamberlin W, Borody T, Graham DY, McNees A, et al. The Consensus from the Mycobacterium avium ssp. paratuberculosis (MAP) Conference 2017. Front Public Health. (2017) 5:208. doi: 10.3389/fpubh.2017.00208
37. Allen AJ, Stabel JR, Robbe-Austerman S, Park KT, Palmer MV, Barrington GM, et al. Depletion of CD4 T lymphocytes at the time if infection with $M$. avium subsp paratuberculosis does not accelerate disease progression. Vet Immunol Immunpathol. (2012) 149:286-91. doi: 10.1016/j.vetimm.2012.07.010

38. Park KT, Allen AJ, Barrington GM, Davis WC. Deletion of relA abrogates the capacity of Mycobacterium avium paratuberculosis to establish an infection in calves. Front Cell Infect Microbiol. (2014) 4:64. doi: 10.3389/fcimb.2014. 00064

39. Lauer KB, Borrow R, Blanchard TJ. Multivalent and multipathogen viral vector vaccines. Clin Vaccine Immunol. (2017) 24:e00298-16. doi: 10.1128/CVI.00298-16

40. Baron MD, Iqbal M, Nair V. Recent advances in viral vectors in veterinary vaccinology. Curr Opin Virol. (2018) 29:1-7. doi: 10.1016/j.coviro.2018. 02.002

41. Thole JE, Wieles B, Clark-Curtiss JE, Ottenhoff TH, Rinke de Wit TF. Immunological and functional characterization of Mycobacterium leprae protein antigens: an overview. Mol Microbiol. (1995) 18:791-800. doi: 10.1111/j.1365-2958.1995. 18050791.x

42. Pethe K, Aumercier M, Fort E, Gatot C, Locht C, Menozzi FD. Characterization of the heparin-binding site of the mycobacterial heparinbinding hemagglutinin adhesin. J Biol Chem. (2000) 275:14273-80. doi: $10.1074 /$ jbc.275.19.14273

43. Duret L, Mouchiroud D. Expression pattern and, surprisingly, gene length shape codon usage in Caenorhabditis, Drosophila, and Arabidopsis. Proc Nat Acad Sci USA. (1999) 96:4482-7. doi: 10.1073/pnas.96.8.4482

44. Gustafsson C, Govindarajan S, Minshull J. Codon bias and heterologous protein expression. Trends Biotechnol. (2004) 22:346-53. doi: 10.1016/j.tibtech.2004.04.006

45. Lee SF, Li YJ, Halperin SA. Overcoming codon-usage bias in heterologous protein expression in Streptococcus gordonii. Microbiology. (2009) 155:3581-8. doi: 10.1099/mic.0.030064-0

Conflict of Interest: The authors declare that the research was conducted in the absence of any commercial or financial relationships that could be construed as a potential conflict of interest.

Copyright (C) 2019 Franceschi, Mahmoud, Abdellrazeq, Tebaldi, Macchi, Russo, Fry, Elnaggar, Bannantine, Park, Hulubei, Cavirani, Davis and Donofrio. This is an open-access article distributed under the terms of the Creative Commons Attribution License (CC BY). The use, distribution or reproduction in other forums is permitted, provided the original author(s) and the copyright owner(s) are credited and that the original publication in this journal is cited, in accordance with accepted academic practice. No use, distribution or reproduction is permitted which does not comply with these terms. 